\title{
The Effects of Climate Change on Variability of the Growing Seasons in the Elbe River Lowland, Czech Republic
}

\author{
Vera Potopová, ${ }^{1}$ Pavel Zahradníček, ${ }^{2}$ Luboš Türkott, ${ }^{1}$ Petr Štěpánek, ${ }^{3}$ and Josef Soukup ${ }^{1}$ \\ ${ }^{1}$ Department of Agroecology and Biometeorology, Faculty of Agrobiology, Food and Natural Resources, \\ Czech University of Life Sciences Prague, Kamycka 129, Prague 6-Suchdol, 16521 Prague, Czech Republic \\ ${ }^{2}$ Global Change Research Centre AS CR, Bělidla 986/4a, 60300 Brno, Czech Republic \\ ${ }^{3}$ Czech Hydrometeorological Institute, Kroftova 43, 61600 Brno, Czech Republic
}

Correspondence should be addressed to Vera Potopová; potop@af.czu.cz

Received 9 January 2015; Accepted 10 February 2015

Academic Editor: Marcos Heil Costa

Copyright (C) 2015 Vera Potopová et al. This is an open access article distributed under the Creative Commons Attribution License, which permits unrestricted use, distribution, and reproduction in any medium, provided the original work is properly cited.

This research aimed to identify an approach for adaptation of agriculture to increased climate variability and projected changes, taking into account regional specificity of climate change. Changes in the timing of growing season (GS) parameters for both observation and models data were computed using daily mean temperatures for three thresholds that correspond to the physiological requirements of the vegetable types. This research included a new assessment of the potential impacts of climate change on the GS of vegetables grown in the Elbe River lowland, one of the largest farmed vegetable regions in Central Europe. To accomplish this, a comprehensive analysis was conducted of the spatiotemporal variability of the date of the beginning of the growing season (BGS), the date of the end of the growing season (EGS), and the length of the growing season (GSL) for the period 1961-2011. In addition, an assessment was made of the potential changes in the dates of the BGS, EGS, and GSL for the Elbe River lowland, simulated using the regional climate models. Prospective areas for growing thermophilic vegetables in the study region were also determined.

\section{Introduction}

The agricultural sector is increasingly exposed to risks, both environmental and economic, due to the phenomenon of climate change and climate variability. In this context, the identification of the best adaptation options is one of the major challenges to improve the risk management tools in agricultural sector at regional and local levels. The Summary for Policymakers of the Working Group I contribution to the IPCC Fifth Assessment Report shows that the risk of extreme events is growing due to global warming [1]. Climate change is likely to affect agricultural systems very differently in various parts of Europe [2]. In northern areas, climate change may have primarily positive effects through increases in productivity and in the range of varieties grown, while in southern areas the disadvantages of climate change will predominate, with lower harvestable yields, higher yield variability, and a reduction in suitable areas for traditional crops. The results of studies performed in Europe in recent years have shown consistent increases in temperature and various patterns of precipitation, with widespread increases in northern Europe and rather small decreases in southern Europe $[3,4]$. These changes in climate patterns are expected to affect all components of Europe's agricultural ecosystems (e.g., crop suitability, yields, and crop protection). Thus, adaptation strategies should be introduced to reduce the negative effects and exploit the possible positive effects of climate change (e.g., changes in crop species, cultivars, and sowing dates).

Future climate change is projected to increase the length of the growing season $[3,5]$. An increase in the length of the growing season, together with warmer climate during the growing season, may increase the potential for growing thermophilic vegetables in open fields in lowland areas in Central Europe and increase the potential number of harvests. For spring crops, climate warming will allow earlier planting or sowing than at present. Earlier planting in spring increases the length of the growing season; thus, earlier planting 
using long-season cultivars will increase yield potential if soil moisture is adequate and the risk of heat stress is low [6]. All the reported studies concern Europe, where recent warming has clearly advanced a significant part of the agricultural calendar. Increased temperatures, associated with earlier late spring frost dates and delayed autumn frost dates, are clearly apparent in temperate regions of Europe [3,7-9]. Advances in production due to earlier springs have been documented for several types of crops $[5,10]$, and the benefits to viticulture of longer growing seasons have been established $[11,12]$. For example, according to [5], the growth stages of wild plants and fruit trees as perennial crops have advanced significantly since the beginning of the 1980s and were, together with true agricultural phases, occurring 1 to 2 weeks earlier by the 2000s. European viticulture has experienced direct effects of climate changes, mainly in terms of shifts in grapevine phenological events and stages. Reference [12], exploring viticulture and climate change relationships in Greece, noted a systematic shift in grape harvest dates (earlier harvests). Similar trends have been observed in Italy. Grape maturity dates have gradually shifted $19 \mathrm{~d}$ earlier over the period 19612009 for numerous varieties [11].

According to [13], the combination of increased air temperature and changes in the amount and annual cycle of precipitation will lead to further shifts in the area and location of individual agroclimatic zones in Central Europe. It is worth noting that, due to climate change, the breeding of new and improved vegetable crop varieties can lead to an extension of the border areas suitable for the profitable cultivation of vegetables. Some thermophilic vegetables that currently grow mostly in southern Europe (e.g., melons, eggplants, tomatoes, and peppers) can become more suitable for cultivation in lowland areas in Central Europe. The two important field vegetable regions in the Czech Republic are South Moravia and the Elbe River lowlands, in which partially different assortments of vegetables are grown. The Elbe River lowland has traditionally been a region of cultivation of brassica vegetables (kohlrabi, Savoy cabbage, white-headed cabbage, and cauliflower), while South Moravia is a profitable region for thermophilic vegetables (e.g., tomatoes and peppers). These differences in the assortments of cultivated vegetables grown in the two regions are mainly due to differences in the temperature conditions of these regions. In the warmest parts of the Elbe River lowland, growing thermophilic vegetables such as tomatoes (Solanum lycopersicum L.) and cucumbers (Cucumis sativus L.) are profitable only in warmer years. Based on our previous studies $[9,14]$, we note that the combination of changes in European agricultural commodities and ongoing climate changes (increases in temperatures) can lead to higher costs for vegetable imports and stricter requirements for the maturity and quality of yields. In addition, favourable national agricultural policies could extend the areas suitable for thermophilic field vegetables from the hottest regions of South Moravia to the Elbe region. In addition to the current assortment of vegetables grown, nontraditional vegetables such as melons (Cucumis melo L.) and eggplants (Solanum melongena L.) could also be grown.

Vegetable crops are most sensitive to the timing of cold events at the beginning and end of the growing season.
Damage caused by late frosts in the spring or early frosts in the fall is a limiting factor, particularly for vegetables grown in Central Europe. In previous study [9], we examined the variations in the last spring frost, the first fall frost, and the length of the frost-free period for the Elbe River lowland in the Czech Republic as indicators of climate variations in this region. Our results demonstrated shifts toward earlier last spring frosts, later first fall frosts, and longer frost-free periods in the Elbe River lowland. Longer frost-free periods can be particularly beneficial for thermophilic vegetables in lowlands. In terms of the growth of field vegetables, however, a late spring frost remains a risk factor, although the degree of risk has decreased [9].

Despite the observed regional trends in agroclimatic characteristics $[9,14]$ and the importance of the horticultural sector to the economy of the Czech Republic, there is an utter lack of research on the impacts of climate variability on the assortment of field vegetables grown in the Elbe River lowland. This subject continues to be of interest to agroclimatologists, although the range and yield of vegetable crops grown in Central Europe are primarily controlled by temperature. Therefore, the primary objective of this study was to evaluate the long-term changes in the timing of the growing season (GS) parameters over the Elbe River lowland for 1961-2011 at a high horizontal resolution using daily mean temperatures for three thresholds $\left(T_{\text {mean }} \geq 5,10\right.$, and $15^{\circ} \mathrm{C}$ ) that correspond to the physiological requirements of the vegetable types. To provide more information on the potential for extension of the range of vegetables grown, the specific objectives of the present study were (i) to conduct a comprehensive analysis of the spatiotemporal variability of the dates of the beginning (BGS) and end (EGS) of the growing season and the length of the growing season (GSL) for three threshold temperatures for the period 1961-2011; (ii) to assess potential changes in the BGS, EGS, and GSL for three threshold temperatures in the Elbe River lowland as simulated using the regional climate models (ALADINClimate/CZ and RegCM) under the A1B SRES scenario (for the periods 2021-2050 and 2071-2100); and (iii) to determine prospective areas for growth of thermophilic vegetables in the study region based on projected climatic data provided by regional climate models.

\section{Data and Methods}

2.1. Gridded Datasets and Quality Control. The Elbe River lowland is one of the largest and most productive suppliers of vegetables in the Czech Republic (Figure 1). The study was based on gridded 116 grid points' daily series of mean air temperature $\left(T_{\text {mean }}\right)$ data at a $10 \mathrm{~km}$ horizontal resolution for observed (1961-2011) and future (2021-2050 and 2071-2100) climate conditions. A regular gridded network (CZGRIDS, ALADIN-Climate/CZ) established by the Czech Hydrometeorological Institute (CHMI) was applied (Figure 1). High-density gridded datasets allow very precise and detailed delimitation of areas with advanced and/or delayed growing seasons compared with station network datasets. The gridded network was created using the technical series from 268 climatological stations and 774 rain gauge stations in the 


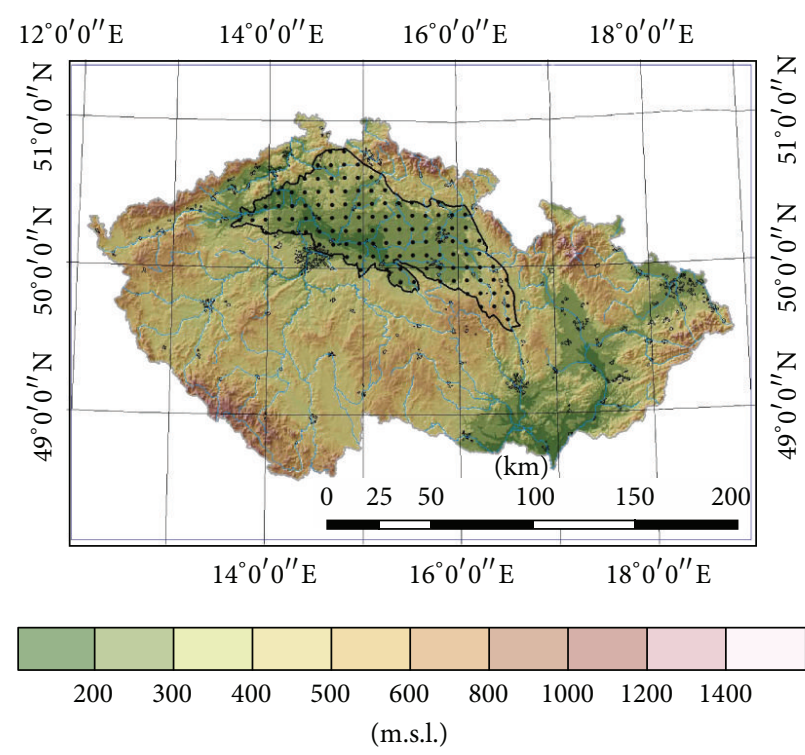

(a)

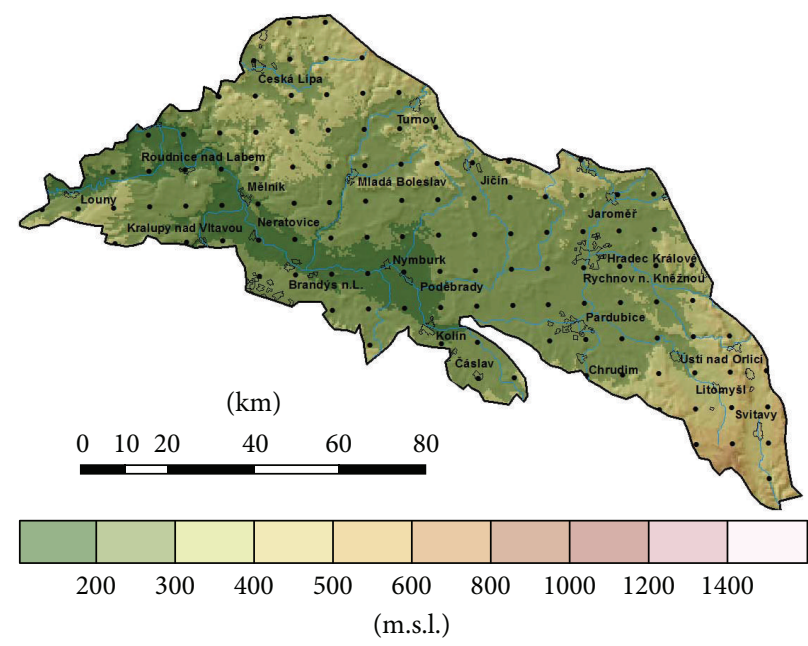

(b)

Figure 1: The boundaries of Elbe River lowland in the Czech Republic and location of the 116 grid points and their elevation (m a.s.l.) in the Elbe River lowland (a) and the relief map of Elbe River lowland (b).

CHMI network (series after quality control, homogenization, and filling of all missing values in the period 1961-2011). New values for the regular $10 \times 10 \mathrm{~km}$ grid network were interpolated from these technical series [15]. The gridding and all data processing, including the analyses described in this paper, were performed using the ProClimDB database software for climatological dataset processing.

A remarkable aspect of vegetable production is that plants function within quite narrow temperature limits. The extreme temperature range is between the killing frost temperature of $0^{\circ} \mathrm{C}$ and death by heat and desiccation at $40^{\circ} \mathrm{C}$ [16]. The wide range of vegetables grown in the studied region can be divided into three basic types according to their sensitivity to low temperatures at the onset of the growing season: thermophilic vegetables (e.g., tomato, pepper, pumpkins, and cucumber), cold-resistant vegetables (e.g., early kohlrabi, summer savoy cabbage, late cauliflower, late cabbage, late carrots, and celeriac), and frost-resistant vegetables (e.g., onion and root parsley). From an agronomic point of view, thermophilic vegetables should be planted after 15 May to minimise the risk of frost damage [9]. The critical temperature for thermophilic vegetables after May 15 is $T \min \leq-0.1^{\circ} \mathrm{C}$ [17-19]. A severe last spring frost after April 15 has occurred every second year during the sowing/planting of cold-resistant vegetables at higher altitudes. Typically, the date of planting/sowing of frost-resistant vegetables in the Czech Republic is at the end of March, and a gradual shift occurs from the hottest regions of South Moravia towards the Elbe region.

2.2. Regional Climate Models and Data Postprocessing. Additionally, the ALADIN-Climate/CZ and RegCM regional climate models (RCMs) were adopted to calculate possible shifts in the start, end, and length of the climatological growing season under the SRES A1B scenario for two future periods
(2021-2050 and 2071-2100) over the Elbe lowland. SRES scenario AlB is a baseline scenario referred to in [19]. We used two different RCMs, which were driven by two different global circulation models (GCM), namely, ARPÉGE-Climate [20] and ECHAM5 [21].

The RegCM model was originally developed [22] and then augmented and used in various reference and scenario simulations [23, 24]. RegCM family using RegCM transient ENSEMBLES run for whole Europe currently in $25 \mathrm{~km}$ resolution driven by transient run of ECHAM5, but within CECILIA-FP6 Project (Central and Eastern Europe Climate Change Impact and Vulnerability Assessment) was developed RegCM in $10 \mathrm{~km}$ resolution, because is important for impact studies in regional scale [25].

ALADIN-Climate/CZ performs quite well in comparasion to the other RCMs in impact studies $[26,27]$. The model is able to capture the main features of the present climate of the Czech Republic and works well over smaller areas with rather complex orography (tablelands, valley, and hills), such as the Elbe River lowland. However, it should be always kept in mind that model simulations of future climate conditions involve many uncertainties, and it is necessary to apply some type of postprocessing of model outputs from the RCM simulation before using the results in other applications. Therefore, the observed daily temperature data were first transferred onto a regular grid of the RegCM and ALADIN-Climate/CZ models. Prior to the calculation of the start, end, and length of the climatological growing season for the RegCM simulations forced with the ECHAM5 GCM and ALADIN-Climate/CZ run forced by ARPÉGE-Climate GCM, the daily temperature for each grid point has been bias corrected against the systematic errors induced by the GCM. The bias correction was applied to the scenario runs. The bias correction method is based on variable correction using 


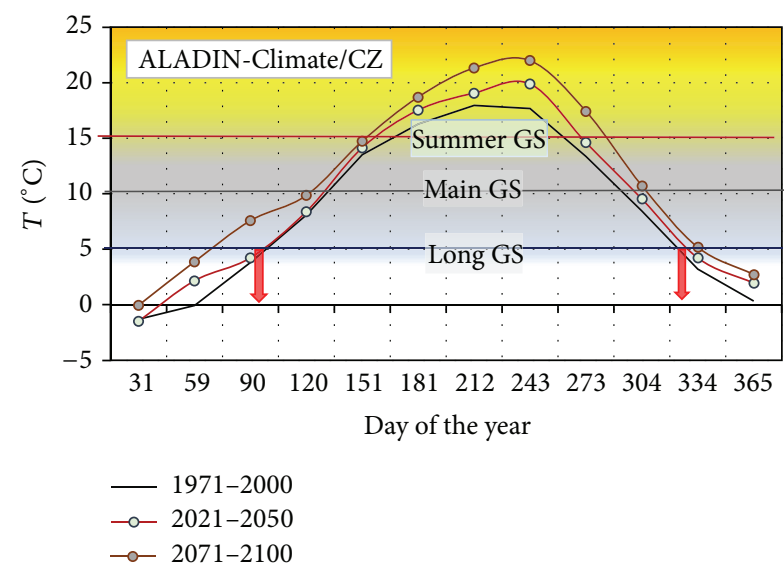

(a)

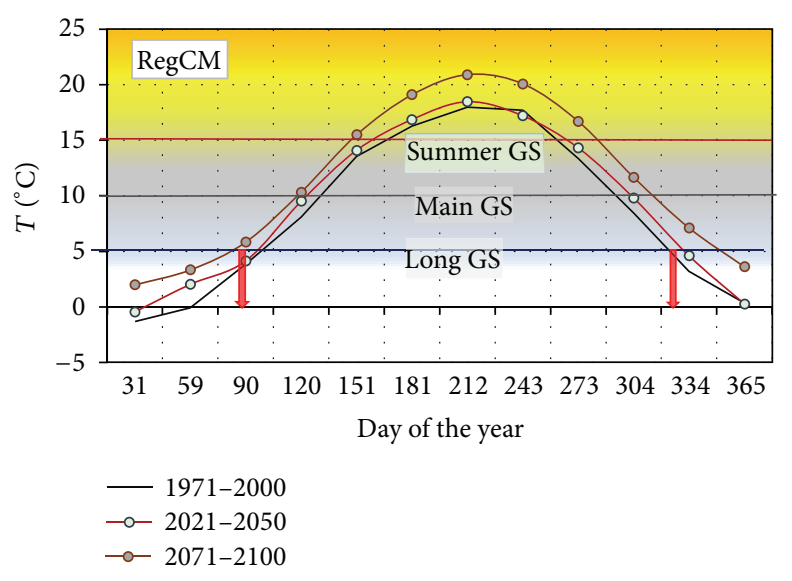

(b)

FIGURE 2: Daily temperatures for observed gridded dataset (1971-2000) and ALADIN-Climate/CZ and RegCM simulation values after bias correction for A1B scenario runs (2021-2050 and 2071-2100) for Elbe River lowland. Schematic delimitation of the long growing season $\left(T_{\text {mean }} \geq 5^{\circ} \mathrm{C}\right)$, the main growing season $\left(T_{\text {mean }} \geq 10^{\circ} \mathrm{C}\right)$, and the summer growing season $\left(T_{\text {mean }} \geq 15^{\circ} \mathrm{C}\right)$ is included.

individual percentiles whose relationships are derived from observations and a control RCMs simulation [28]. After the correction, the model outputs (for 2021-2050 and 2071-2100) were fully compatible with the gridded observation dataset (1971-2000). Figure 2 shows the annual variation of bias corrected daily temperature means calculated for 30 years, corresponding to the RegCM (forced by ECHAM5) and ALADIN-Climate/CZ (forced by ARPÉGE-Climate) in the A1B scenario runs (2021-2050 and 2071-2100), respectively. The results show that the projected temperature means for all months in the A1B scenario runs will increase compared to the current climate (1971-2000).

For the Czech Republic as a whole, ALADIN-Climate/CZ and RegCM simulated increases in temperature, especially in the summer and winter. Over the Elbe lowland region, the temperatures are projected to increase by the end of the 21st century compared to the mid-21st century and the reference period 1971-2000. The 30-year annual temperature means for the Elbe lowland are $8.4^{\circ} \mathrm{C}$ for the current climate (19712000) and $9.6^{\circ} \mathrm{C}$ for $2021-2050$ and $11.4^{\circ} \mathrm{C}$ for $2071-2100$. The mean summer temperature increases over all models are projected to be $1.7^{\circ} \mathrm{C}$ and $4.0^{\circ} \mathrm{C}$ in $2021-2050$ and $2071-2100$, respectively, relative to $1971-2000$. The projected increases in the spring and autumn temperature means under the $\mathrm{AlB}$ scenario are $0.5^{\circ} \mathrm{C}$ and $2.3^{\circ} \mathrm{C}$, respectively, in $2021-2050$ and $1.1^{\circ} \mathrm{C}$ and $2.8^{\circ} \mathrm{C}$, respectively, in $2071-2100$. Overall, these projections suggest increase in the GSL in 2071-2100 relative to the present climate. Both RCMs simulations for the A1B SRES scenario reveal that the summer temperature, which has an important influence on the beginning and end of the GS $\geq 15^{\circ} \mathrm{C}$ in hilly areas, will increase by the end of the 21st century. Increasing temperatures can lead to earlier harvests of thermophilic vegetables. However, responses to temperature changes may differ among vegetable varieties, mainly in terms of their temperature thresholds for optimum ripening [16].
2.3. Determination of BGS, EGS, and GSL. The effect of climate change on the GS of agricultural crops can be determined through phenological observations, the normalised difference vegetation index from satellite data, and surface air temperatures [7, 29-36]. Definitions of the growing season using surface air temperatures may be considered valid in areas where the GS is largely limited by temperature. In our study, we used threshold temperatures for a predefined number of days to start and end the climatological GS, which has good spatial coverage over the regular grid network. However, there is no universal definition of the climatological GS depending on the geographic position and associated climate regimes, and there may be large disagreement in GSL changes depending on the definition used [34]. The climatological GS can be defined as the entire period in which growth can theoretically take place [31]. In an attempt to provide a common benchmark for investigators, [32] selected the $5^{\circ} \mathrm{C}$ threshold to standardise the definition of the GS as the period when daily temperatures remain above $5^{\circ} \mathrm{C}$ for more than 5 days. Reference [31] defined the start of the GS as $>5^{\circ} \mathrm{C}$ for $\geq 5$ days and the end as a 10-day period of mean daily temperatures below $5^{\circ} \mathrm{C}$. In the Greater Baltic Area, [34] defined the start of the growing season as the last day of the first six-day period with daily mean temperatures above $5^{\circ} \mathrm{C}$ after the last winter/spring frost. In our study, the GS parameters were defined with respect to the physiological requirements of the vegetable types and the classification system of the Climate Atlas of Czechia [37] (the large growing season $\left(T_{\text {mean }} \geq 5^{\circ} \mathrm{C}\right)$, the main growing season $\left(T_{\text {mean }} \geq\right.$ $\left.10^{\circ} \mathrm{C}\right)$, and the summer growing season $\left(T_{\text {mean }} \geq 15^{\circ} \mathrm{C}\right)$ ).

The sowing/planting period differs among field vegetable types; therefore, we defined the BGS as the first five consecutive days during which the daily mean temperature equals or exceeds 5,10 , or $15^{\circ} \mathrm{C}$ and, subsequently, does not drop below $T_{\text {mean }} 5,10$, or $15^{\circ} \mathrm{C}$ for five days or more. The EGS is defined as the first day of the first 5 -day period with a $T_{\text {mean }}$ below 5 , 
TABLE 1: Statistical characteristics of the area-averaged growing season parameters of the studied area for 1961-2011.

\begin{tabular}{|c|c|c|c|c|c|c|c|c|c|}
\hline & \multicolumn{3}{|c|}{$T_{\text {mean }} \geq 5^{\circ} \mathrm{C}$} & \multicolumn{3}{|c|}{$T_{\text {mean }} \geq 10^{\circ} \mathrm{C}$} & \multicolumn{3}{|c|}{$T_{\text {mean }} \geq 15^{\circ} \mathrm{C}$} \\
\hline & Start & End & Length & Start & End & Length & Start & End & Length \\
\hline Median & 26 Mar. & 4 Nov. & 223 & 21 Apr. & 7 Oct. & 169 & 21 May & 7 Sep. & 109 \\
\hline STDev & 10.1 & 12.9 & 15.7 & 10.4 & 9.7 & 14.3 & 15.2 & 11.0 & 18.0 \\
\hline Earliest/shortest & $\begin{array}{l}4 \text { Mar. } \\
(1990)\end{array}$ & $\begin{array}{l}12 \text { Oct. } \\
(1994)\end{array}$ & $\begin{array}{c}188 \\
(1997) \\
\end{array}$ & $\begin{array}{c}30 \text { Mar. } \\
\text { (1998) }\end{array}$ & $\begin{array}{l}\text { 16 Sep. } \\
(1972)\end{array}$ & $\begin{array}{c}136 \\
(1972) \\
\end{array}$ & $\begin{array}{l}21 \text { Apr. } \\
\text { (1962) }\end{array}$ & $\begin{array}{c}19 \text { Aug. } \\
(1978)\end{array}$ & $\begin{array}{c}67 \\
(1965) \\
\end{array}$ \\
\hline Latest/longest & $\begin{array}{c}16 \text { Apr. } \\
(1997)\end{array}$ & $\begin{array}{l}8 \text { Dec. } \\
(2006)\end{array}$ & $\begin{array}{c}256 \\
(2006) \\
\end{array}$ & $\begin{array}{c}22 \text { May } \\
(1980)\end{array}$ & $\begin{array}{l}28 \text { Oct. } \\
(2000)\end{array}$ & $\begin{array}{c}195 \\
(2000) \\
\end{array}$ & $\begin{array}{l}26 \text { Jun. } \\
(1974)\end{array}$ & $\begin{array}{c}30 \text { Sep. } \\
(1966)\end{array}$ & $\begin{array}{c}151 \\
(2000)\end{array}$ \\
\hline
\end{tabular}

10 , or $15^{\circ} \mathrm{C}$. The GSL is the number of days between the BGS and EGS for the three threshold temperatures. Using the three thresholds of daily $T_{\text {mean }}$ is justified because they correspond to the vegetation period of the majority of field vegetables. $\mathrm{BGS} \geq 5^{\circ} \mathrm{C}$ represents the average date of the sowing period of the majority of field frost-resistant vegetables, whereas the start of BGS $\geq 10$ and $15^{\circ} \mathrm{C}$ corresponds to the sowing/planting periods of field cold-resistant and thermophilic vegetables, respectively, in the studied region. The EGS corresponds to the harvest period of different types of vegetable crops. The GSL is the time from sowing to harvest or the time from planting to harvest.

Using these definitions, we produced time series of the start, end, and length of the growing season for 116 grid points for both the observations and the model datasets. Furthermore, we created and statistically processed two datasets. First, to characterise the spatial patterns of the GS parameters, the annual BGS, EGS, and GSL series for the three thresholds were averaged at each grid point for the current climate (1961-2011) and two future climates (20212050 and 2071-2100). Second, to examine temporal variations in the GS parameters over the Elbe River lowland as a whole, the BGS, EGS, and GSL for the three thresholds were arithmetically averaged over all 116 grid points to obtain a time series for the current climate (1961-2011) and the two future climates (2021-2050 and 2071-2100). Then, projected changes in the dates of the start and end and the length of the growing season are analyzed by comparing the model simulations for the periods 2021-2050 and 2071-2100 with the reference period 1971-2000.

To investigate changes in the timing of the observed GS parameters, regional anomalies in the start, end, and length of the growing season for the three thresholds over the Elbe River lowland from 1961 to 2011 were calculated. Positive anomalies indicate dates later in the year (fall and spring occurrences) or a greater number of days (length). We then classified anomalies in the growing season onset, end, and length into two categories: (1) years with advances and/or increases in the growing seasons and (2) years with delays and/or decreases in the growing seasons. We also calculated linear trends and analysed the regression slopes of the GS parameters and assessed their significance using Student's one-tailed $t$-test. Finally, to identify prospective areas for growing thermophilic vegetables, kriging interpolation tools in ArcGIS software were used to create maps of the spatial distributions of the GS parameters for the current and future climate conditions. Interpolation, where needed, is based on local linear regression (dependence of given meteorological element on altitude) and universal kriging interpolation method. To generate the maps at regional scale we used CLIDATA GIS environment and CLIDATA DEM (digital elevation model) method with a horizontal resolution of $500 \mathrm{~m}$ and $40 \mathrm{~km}$ radius of regression.

\section{Results and Discussion}

\subsection{Climatology of the Beginning, End, and Length of Growing Seasons}

3.1.1. The Long Growing Season: $T_{\text {mean }} \geq 5^{\circ} \mathrm{C}$. The analysis domain was averaged to evaluate interannual variations in the start, end, and length of the growing season for the three thresholds $\left(T_{\text {mean }} \geq 5,10\right.$, and $\left.15^{\circ} \mathrm{C}\right)$ over the Elbe River lowland as a whole. The beginning of field sowing for the majority of frost-resistant vegetables corresponds to the transition of the average daily temperature through $5^{\circ} \mathrm{C}$. The long-term average (1961-2011) starts and ends of the growing season for $T_{\text {mean }} \geq 5^{\circ} \mathrm{C}$ range from March 26 to November 4 , and the growing season lasts 223 days on median (Table 1). A shortening of the growing season by 35 days compared with the long-term average occurred in 1997 due to a delayed start of $\mathrm{BGS} \geq 5^{\circ} \mathrm{C}$ by 21 days. A lengthening of the growing season by 33 days compared with the long-term average occurred in 2006 due to a delayed EGS. The earliest beginning of the growing season was observed in 1990, with an onset of 22 days earlier than the regional average (4 March) (Tables 1 and 2). The onset of spring was very early in 1990 due to temperature anomalies from February to the second half of March that resulted in $T_{\text {mean }}$ deviations from +5.0 to $+11.0^{\circ} \mathrm{C}$. The GSL in 1990 also ranked among the four longest growing seasons between 1961 and 2011 (Table 2). In this year, the anomalies in the BGS in Central Europe (up to -27 days) were due to temperature anomalies of up to $+4.5^{\circ} \mathrm{C}$ that occurred from February to April. These findings are similar to those reported by [7]. The earliest EGS $\geq 5^{\circ} \mathrm{C}$ date was recorded in 1994 (October 12). In this year, the EGS was 23 days earlier, on average, throughout the Elbe lowland. A marked cooling associated with a low-pressure trough occurred in the first half of October. This low-pressure trough was associated with individual frontal systems that progressed from west to east across Europe and led to low-temperature anomalies. The latest EGS $\geq 5^{\circ} \mathrm{C}$ occurred in 2006, approximately 34 
TABLE 2: Area-averaged anomalies (sorted by the highest number of anomalies in days) in the start, end, and length of the growing season for the three thresholds of $T_{\text {mean }} \geq 5,10$, and $15^{\circ} \mathrm{C}$ over the Elbe River lowland for 1961-2011.

\begin{tabular}{|c|c|c|c|}
\hline & & Years & Anomalies (days) \\
\hline \multicolumn{4}{|c|}{ Advance/increase of growing season } \\
\hline $\mathrm{BGS} \geq 5^{\circ} \mathrm{C}$ & Early start & 1990, 1981, 1961, 1991, 2007, 2011 & $-22,-18,-17,-17,-14,-14$ \\
\hline $\mathrm{EGS} \geq 5^{\circ} \mathrm{C}$ & Late end & 2006, 2000, 1963, 1969, 2008, 1987, 1996, 2010 & $+34,+28,+20,+18,+17,+16,+15,+12$ \\
\hline $\mathrm{GSL} \geq 5^{\circ} \mathrm{C}$ & Longer & 2006, 2000, 1961, 1990, 2008, 2010, 2011 & $+33,+29,+23,+22,+22,+19,+18$ \\
\hline \multicolumn{4}{|c|}{ Delay/decrease of growing season } \\
\hline $\mathrm{BGS} \geq 5^{\circ} \mathrm{C}$ & Late start & $1997,1970,1962,1975,1996,1969$ & $+21,+18,+17,+15,+13,+12$ \\
\hline $\mathrm{EGS} \geq 5^{\circ} \mathrm{C}$ & Early end & 1994, 2009, 1965, 1991, 1997 & $-23,-21,-18,-15,-15$ \\
\hline $\mathrm{GSL} \geq 5^{\circ} \mathrm{C}$ & Shorter & 1997, 1962, 1975, 1965, 1973, 1979, 1980 & $-35,-30,-25,-23,-17,-17,-13$ \\
\hline \multicolumn{4}{|c|}{ Advance/increase of growing season } \\
\hline $\mathrm{BGS} \geq 10^{\circ} \mathrm{C}$ & Early start & $1998,1974,2009,1981,1961$ & $-22,-20,-19,-17,-15,-8$ \\
\hline $\mathrm{EGS} \geq 10^{\circ} \mathrm{C}$ & Late end & 2000, 2001, 1988, 1967, 1984, 1983, 1991 & $+21,+18,+13,+12,+12,+10,+10$ \\
\hline $\mathrm{GSL} \geq 10^{\circ} \mathrm{C}$ & Longer & 2000, 2009, 1981, 1961, 1998 & $+26,+22,+19,+17,+15$ \\
\hline \multicolumn{4}{|c|}{ Delay/decrease of growing season } \\
\hline $\mathrm{BGS} \geq 10^{\circ} \mathrm{C}$ & Late start & 1980, 1982, 1965, 1970, 1972, 1984, 1987, 1997 & $+31,+22,+21,+13,+13,+11,+11,+10$ \\
\hline $\mathrm{EGS} \geq 10^{\circ} \mathrm{C}$ & Early end & $1977,1972,1971,1996,1970$ & $-22,-21,-16,-15,-14$ \\
\hline $\mathrm{GSL} \geq 10^{\circ} \mathrm{C}$ & Shorter & $1972,1980,1970,1977,1987,1965,1971$ & $-33,-31,-27,-26,-22,-21,-20$ \\
\hline \multicolumn{4}{|c|}{ Advance/increase of growing season } \\
\hline $\mathrm{BGS} \geq 15^{\circ} \mathrm{C}$ & Early start & 1962, 1993, 2000, 1968, 2001, 1986, 1998, 2003 & $-30,-28,-28,-22,-21,-20,-19,-16$ \\
\hline $\mathrm{EGS} \geq 15^{\circ} \mathrm{C}$ & Late end & 1966, 1975, 1989, 2006, 1999, 2003, 2000 & $+23,+22,+18,+17,+17,+14,+13$ \\
\hline $\mathrm{GSL} \geq 15^{\circ} \mathrm{C}$ & Longer & $2000,1966,1993,2003$ & $+41,+32,+31,+30$ \\
\hline \multicolumn{4}{|c|}{ Delay/decrease of growing season } \\
\hline $\mathrm{BGS} \geq 15^{\circ} \mathrm{C}$ & Late start & $1974,1965,1972,1980,1975$ & $+36,+28,+24,+21,+20$ \\
\hline $\mathrm{EGS} \geq 15^{\circ} \mathrm{C}$ & Early end & $1978,1986,1965,1970,1971$ & $-19,-19,-14,-13,-12$ \\
\hline $\mathrm{GSL} \geq 15^{\circ} \mathrm{C}$ & Shorter & $1965,1974,1980,1978,2010,1972,1970$ & $-42,-30,-30,-26,-26,-23,-22$ \\
\hline
\end{tabular}

days later compared with the long-term mean, as a result of the strong positive $T_{\text {mean }}$ anomalies that occurred from September to October. The year 2006 had also the longest $\mathrm{GSL} \geq 5^{\circ} \mathrm{C}$.

3.1.2. The Main Growing Season: $T_{\text {mean }} \geq 10^{\circ} \mathrm{C}$. The beginning of active growth and development of the main field vegetables is considered to correspond to the stable transition of the average daily air temperature through $10^{\circ} \mathrm{C}$. The mean dates of the start and end of the growing season throughout the Elbe lowland for $T_{\text {mean }} \geq 10^{\circ} \mathrm{C}$ are April 21 and October 7, respectively, and the mean growing season length is 169 days (Table 1). The earliest date of BGS $\geq 10^{\circ} \mathrm{C}$ was observed in 1998 (30 March), an advance of 22 days caused by strong positive temperature anomalies (up to $+6.0^{\circ} \mathrm{C}$ ). The onset of spring was also very early this year throughout Central Europe [7]. The reverse was observed in 1980, with the latest date of BGS $\geq 10^{\circ} \mathrm{C}$ observed (May 22, +31 days compared with the long-term average). Moreover, an early end of the growing season in the fall of 1980 resulted in extreme reductions in the GSL $\geq 5^{\circ} \mathrm{C}$ ( -13 days $), \mathrm{GSL} \geq 10^{\circ} \mathrm{C}$ ( -31 days $)$, and GSL $\geq$ $15^{\circ} \mathrm{C}$ ( -30 days) compared with the long-term average (Table 2 ). The length of the growing season significantly affects the vegetable sector. Its extension in the spring allows for early sowing/planting of crops, and its extension in the fall has a positive effect on the production quality, allowing a gradual harvest. The earliest date of EGS $\geq 10^{\circ} \mathrm{C}$ occurred in 1972
(September 16), and the latest date occurred in 2000 (October 28). Consequently, the longest and shortest growing seasons occurred in 2000 (195 days) and 1972 (136 days), respectively.

3.1.3. The Summer Growing Season: $T_{\text {mean }} \geq 15^{\circ} \mathrm{C}$. The period of $T_{\text {mean }} \geq 15^{\circ} \mathrm{C}$ corresponds to the beginning of the transplanting of thermophilic vegetables. The mean dates of the start and end of the growing season for $T_{\text {mean }} \geq 15^{\circ} \mathrm{C}$ are May 21 to September 7, and the mean length of the growing season is 109 days. The earliest date for BGS $\geq 15^{\circ} \mathrm{C}$ occurred in 1962 (21 April), and the latest date occurred in 1974 (26 June). The earliest end of the growing season occurred in 1978 and 1986 (19 August), earlier than the average by -19 days (Tables 1 and 2). The latest end occurred in 1966 (30 September), later than the average by +23 days. The greatest lengthening of the growing season, +42 days compared with the long-term mean, occurred in 2000, and the greatest shortening of the growing season, -42 days compared with the long-term mean, occurred in the cool year of 1965. In 2000 , strong positive temperature anomalies of $3.5^{\circ} \mathrm{C}$ to $5.0^{\circ} \mathrm{C}$ in the daily mean temperatures in April led to an advance in $\mathrm{BGS} \geq 15^{\circ} \mathrm{C}$ of 28 days. In the same year, a significantly longer growing season was recorded, not only in terms of $\mathrm{GSL} \geq 15^{\circ} \mathrm{C}$ but also in terms of GSL $\geq 5^{\circ} \mathrm{C}(+22 \mathrm{~d})$ and GSL $\geq 10^{\circ} \mathrm{C}(+26 \mathrm{~d})$. The growing season was extremely long that year throughout Europe $[7,29]$. 


\subsection{Temporal Variability of the Beginning, End, and Length of Climatological Growing Seasons}

3.2.1. Anomalies in the Start, End, and Length of the Growing Season. Regional anomalies in the start, end, and length of the growing season for the three threshold temperatures in the Elbe River lowland for 1961-2011 are shown in Table 2. Growing seasons with stronger negative and positive anomalies were classified into two categories: (1) years with advances and/or increases in the growing season (i.e., an early start and/or late end) and (2) years with delays and/or decreases in the growing season (i.e., a later start and/or early end). During the second half of the 20th century and the first decade of the 21st century, the years with the largest anomalies in terms of an early start of the growing season $\left(B G S \geq 5^{\circ} \mathrm{C}\right.$ ) were 1990 (-22 d), 1981 (-18 d), 1961 (-17 d), 1991 (-17 d), 2007 $(-14 \mathrm{~d})$, and $2011(-14 \mathrm{~d})$. The years with the largest anomalies in terms of a later end of the growing season, EGS $\geq 5^{\circ} \mathrm{C}$, were 2006 (+34 d), 2000 (+28 d), 1963 (+20 d), 1969 (+18 d), 2008 $(+17 \mathrm{~d}), 1987(+16 \mathrm{~d}), 1996(+15 \mathrm{~d})$, and $2010(+12 \mathrm{~d})$. Thus, an earlier start of $\mathrm{BGS} \geq 5^{\circ} \mathrm{C}$ and a later end of EGS $\geq 5^{\circ} \mathrm{C}$, together with a late end of the growing season, occurred in 1961, 1990, and 2011 (Table 2). However, the years 2010 and 2011 had early fall frosts that occurred during the harvest period for root vegetables (e.g., Apium graveolens). The years with delayed and/or decreased GS $\geq 5^{\circ} \mathrm{C}$ were $1997(-35 \mathrm{~d})$, $1962(-30$ d), 1975 ( -25 d), 1965 (-23 d), 1973 (-17 d), and 1979 $(-17 \mathrm{~d})$. All these years also had a later end of spring and an early beginning of fall frosts [9].

Based on the same selection criteria, the years with advanced and/or increased GS $\geq 10^{\circ} \mathrm{C}$ were $2000(+26 \mathrm{~d})$, $2009(+22 \mathrm{~d}), 1981(+19 \mathrm{~d}), 1961(+17 \mathrm{~d})$, and $1998(+15 \mathrm{~d})$. The years with delayed and/or decreased GS $\geq 10^{\circ} \mathrm{C}$ were 1972 (-33 d), 1980 (-31 d), 1970 (-27 d), 1977 (-26 d), 1987 $(-22 \mathrm{~d}), 1965(-21)$, and $1971(-20 \mathrm{~d})$. The majority of these years appear to be associated with temperature anomalies in Central Europe $[7,8,29]$. Our results are in line with these findings and offer additional insights into the complexity of these phenomena on a regional scale. Although the growing seasons have ended later, the BGS has made a greater contribution to the increase in GSL (1961, 1981, 1998, and 2009) (Table 2). A later start, early end, and shorter GSL occurred in 1970 and 1972. A shortening of the growing season occurred in 1971 and is attributed to an early end of EGS $\geq 10^{\circ} \mathrm{C}$, whereas the shortening of the GS that occurred in 1965 and 1987 is attributed to a later onset of the growing season in those years.

The variability in strong anomalies in the start, end, and length of the growing season for $T_{\text {mean }} \geq 15^{\circ} \mathrm{C}$ is similar to that for $\mathrm{GS} \geq 5$ and $10^{\circ} \mathrm{C}$ (Table 2). Positive anomalies for GSL $\geq 15^{\circ} \mathrm{C}$ were recorded in $2000(+41 \mathrm{~d}), 1966(+32 \mathrm{~d})$, $1993(+31 \mathrm{~d})$, and $2003(+30 \mathrm{~d})$, while negative anomalies were recorded in $1965(-42 \mathrm{~d}), 1974(-30 \mathrm{~d}), 1980(-30 \mathrm{~d})$, 1978 (-26 d), 2010 (-26 d), $1972(-23 \mathrm{~d})$, and $1970(-22 \mathrm{~d})$. For field thermophilic vegetables, a shift in the beginning date of the growing season in the spring months is more advantageous than a change in the growing season length. An early start of $B G S \geq 15^{\circ} \mathrm{C}$, together with a longer GSL $\geq$ $15^{\circ} \mathrm{C}$, was recorded in 1993 (an average advance of $-28 \mathrm{~d}$ and a lengthening of $+31 \mathrm{~d}), 2000(-28 \mathrm{~d}$ and $+41 \mathrm{~d})$, and 2003 $(-16 \mathrm{~d}$ and $+30 \mathrm{~d})$, which led to advanced dates of planting of field thermophilic vegetables in the studied region. These growing seasons appear to be associated with high positive temperature anomalies and high deficits in the water balance (i.e., exceptionally warm and dry spells) throughout the country. The year with the latest start of $\mathrm{BGS} \geq 15^{\circ} \mathrm{C}$, the earliest end of EGS $\geq 15^{\circ} \mathrm{C}$, and the shortest GSL was 1965 . This year has also been identified in previous study of the Czech Republic [14] as having been extremely wet and cold. Late-onset and shortened growing seasons also occurred in 1972,1974 , and 1980, while an early end and shorter GSL $\geq$ $15^{\circ} \mathrm{C}$ occurred in 1970, 1971, and 1978 .

We observed that the majority of years with delays and/or decreases in the growing seasons occurred in the cool and wet decade of 1971 to 1980 , which was characterised with persistently higher than normal precipitation and the lowest negative deviations in daily mean temperatures since 1961. During this decade, the regional average of the ending of mild spring frosts occurred in the second half of May, and the years had shorter frost-free periods [9].

Figure 3 displays the interannual variations of the areaaveraged BGS, EGS, and GSL for average daily temperatures of at least $5^{\circ} \mathrm{C}, 10^{\circ} \mathrm{C}$, and $15^{\circ} \mathrm{C}$ in the Elbe River lowland during the period 1961-2011. As the left panel of Figure 3 shows, the BGS exhibited high interannual variation. Positive anomalies predominated during 1963-1973 for BGS $\geq 5$ and $10^{\circ} \mathrm{C}$ and during $1970-1980$ for $\mathrm{BGS} \geq 15^{\circ} \mathrm{C}$, whereas negative anomalies predominated during 1989-1997 and 2000-2011. Although the annual $\mathrm{BGS} \geq 15^{\circ} \mathrm{C}$ significantly advanced during the 1990s, the signal was reduced in the 2000s. Overall, the long-term variations in BGS exhibited earlier spring features, which are consistent with the findings of other climatological research $[3,34,36]$. Moreover, the majority of phenological studies show similar trends: earlier springs and longer periods of plant growth due to greater changes in the timing of the BGS rather than in the timing of the EGS $[3,34,36]$. The annual changes in EGS also exhibit strong interannual variations (middle panel of Figure 3 ). In contrast to $\mathrm{BGS} \geq 5$ and $10^{\circ} \mathrm{C}$, negative anomalies were observed during 1970-1980, whereas positive anomalies were observed during the 1990s and 2000s, which indicates a delayed EGS in recent decades. Asymmetric long-term variations in BGS and EGS led to increases in the total GSL (right panel of Figure 3). With the weakening of the earlier BGS trends, greater delays in EGS clearly led to longer GSLs from 1995 through the 2000s. Conversely, in the first decade of the 21st century, the GSL $\geq 15^{\circ} \mathrm{C}$ slightly shortened as a result of the delayed start of the growing season; however, the end of EGS $\geq 15^{\circ} \mathrm{C}$ occurred later, which may have had a positive effect on the ripening and quality of thermophilic vegetables. A later onset of GSL $\geq 15^{\circ} \mathrm{C}$ can be mitigated by agrotechnical measures. Using remote measurements of the vegetation index and daily mean temperatures, [35] found that the lengthening of the GS in Europe in the last decade could be attributed mainly to the delay in EGS rather than to the advance of BGS. Moreover, the temporal evolution of GS in different climatic regimes is characterised by large spatial differences. Climatic indicators (e.g., the frost-free period and the thermal growing season), 

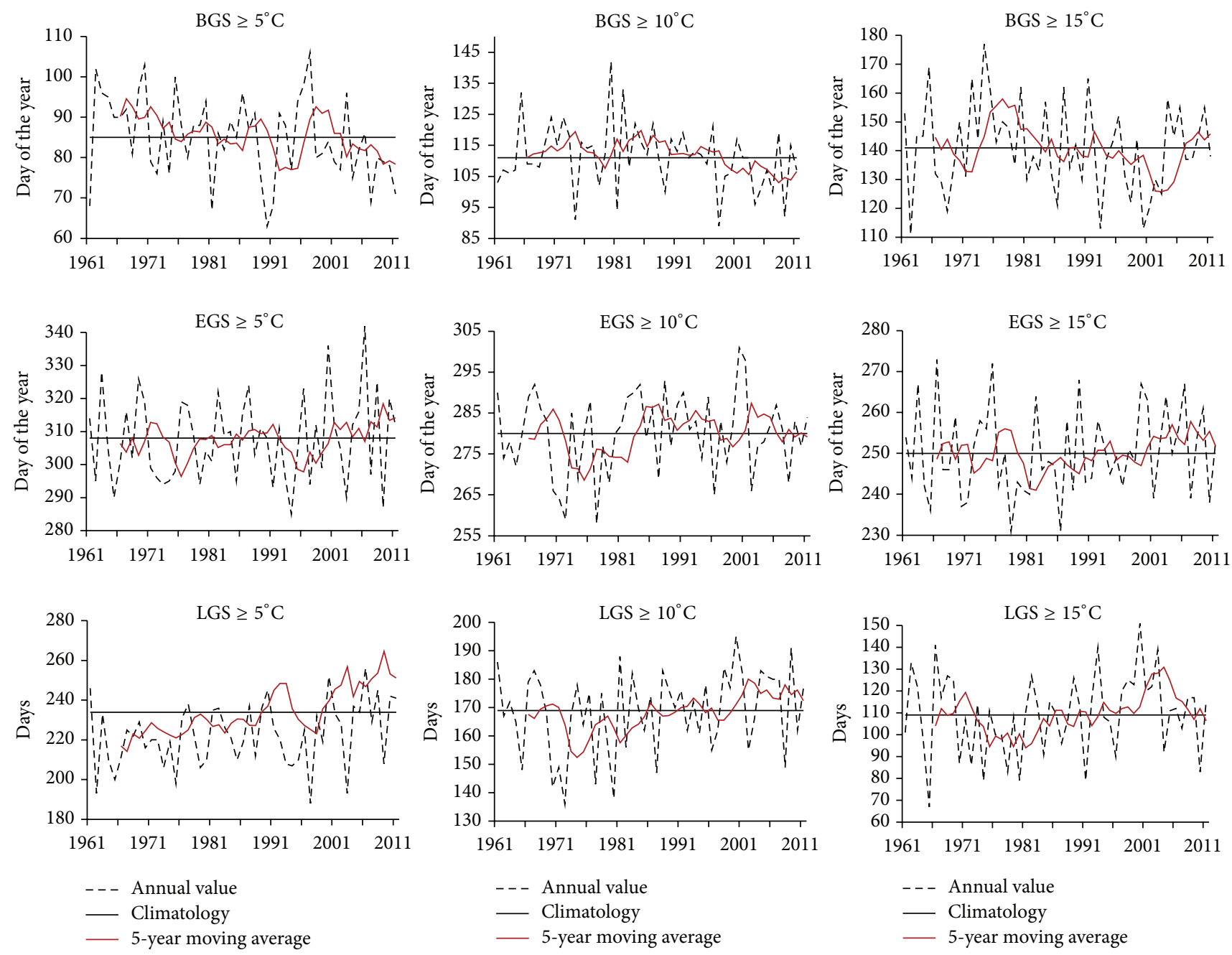

FIGURE 3: Interannual variations of area-averaged BGS (beginning of the growing season), EGS (end of the growing season), and LGS (length of the growing season) for the 5, 10, and $15^{\circ} \mathrm{C}$ temperature thresholds from 1961 to 2011 in the Elbe River lowland. The black line indicates the climatology of each event (average), and the grey line indicates the 5-year moving average of each parameter.

remote sensing-based indicators, and phenological studies all indicate shifts in the timing and length of the growing season $[3,5,7,8,10,31,32,34,36]$.

3.2.2. Trends of the Growing Season. To obtain additional insights into the changes in the timing of the GS parameters in the area-averaged time series, the linear trends and regression slopes of the growing season onset, end, and length were calculated. The significance of these trends was tested using Student's one-tailed $t$-test at the $95 \%$ significance level. The linear trends of the beginning, end, and length of the growing season are tabulated in Table 3. Increasingly negative BGS trends and positive EGS trends led to increasing GSL trends. Over a 51-year period, the GS $\geq 5^{\circ} \mathrm{C}$ started 10.7 days earlier and ended 4.6 days later, yielding an increase in the GSL of 15.3 days. The $\mathrm{BGS} \geq 10^{\circ} \mathrm{C}$ advanced by 7.6 days on average, and the EGS $\geq 10^{\circ} \mathrm{C}$ was delayed by 3.6 days on average, resulting in an average lengthening of the GSL $\geq 10^{\circ} \mathrm{C}$ by 11.2 days. The GSL $\geq 15^{\circ} \mathrm{C}$ advanced by only 5.1 days, with smaller changes during the spring (1.0 day) than in the fall (4.1 days).
To understand the evolution of significant changes in the growing season series, the analysis period was divided into five decades (Table 3). The results suggest that the Elbe lowland has experienced the following changes in its growing season parameters over the last five decades. (1) Although advances in the BGS have been reported as the main factor in longer growing seasons, in this study, delays in the EGS were found to be a more important factor regulating GSL changes during the 1990s and 2000s at thresholds of $T_{\text {mean }} \geq 15^{\circ} \mathrm{C}$. (2) We found that the GSL $\geq 5$ and $10^{\circ} \mathrm{C}$ increased considerably during 1991-2000 ( $>0.77$ days $\left.\mathrm{yr}^{-1}\right)$, but the lengthening was less pronounced during 1961-1970 and 1971-1980. (3) The largest changes in the start of BGS $\geq 5$ and $10^{\circ} \mathrm{C}$ (earlier growing season starts of approximately one week) in the 2000s occurred because of warmer temperatures and earlier ends of the last frosts. (4) General trends towards later growing season ends were observed, except for 19611970 , for which shifts of -0.7 and -6.3 days decade ${ }^{-1}$ towards an earlier growing season end were observed. (5) In the Elbe River lowland, BGS and EGS exhibited shifts towards earlier 
TABLE 3: Observed long-term changes (days per year) in growing season parameters over the Elbe River lowland.

\begin{tabular}{lccccccccc}
\hline & \multicolumn{3}{c}{$T_{\text {mean }} \geq 5^{\circ} \mathrm{C}$} & \multicolumn{3}{c}{$T_{\text {mean }} \geq 10^{\circ} \mathrm{C}$} & \multicolumn{3}{c}{$T_{\text {mean }} \geq 15^{\circ} \mathrm{C}$} \\
& Start & End & Length & Start & End & Length & Start & End & Length \\
\hline $1961-1970$ & +0.91 & -0.07 & $-0.98^{*}$ & +0.95 & -0.27 & $-1.22^{* *}$ & +0.49 & -0.63 & $-1.12^{*}$ \\
$1971-1980$ & +0.80 & +0.19 & $-0.61^{*}$ & +0.90 & +0.01 & $-0.89^{*}$ & -0.06 & -0.33 & $-0.27^{*}$ \\
$1981-1990$ & -0.38 & +0.11 & $+0.49^{* *}$ & -0.41 & +0.40 & $+0.81^{*}$ & -0.09 & +0.30 & $+0.39^{*}$ \\
$1991-2000$ & -0.76 & +0.01 & $+0.77^{*}$ & -0.82 & +0.05 & $+0.87^{*}$ & -0.10 & +0.36 & $+0.46^{*}$ \\
$2001-2010$ & -0.54 & +0.67 & $+1.21^{* *}$ & -0.56 & +0.06 & $+0.62^{*}$ & -0.01 & +0.56 & $+0.57^{*}$ \\
$1961-2011$ & -0.21 & +0.09 & $+0.30^{* * *}$ & -0.15 & +0.07 & $+0.22^{* * *}$ & -0.02 & +0.08 & $0.10^{* *}$ \\
\hline
\end{tabular}

${ }^{*}$ Marginally significant $(0.01<P \leq 0.05) ;{ }^{* *}$ significant $(0.001<P \leq 0.01) ;{ }^{* * *}$ highly significant $(P \leq 0.001)$.

and later dates, respectively. However, from 1981 to 2000 , the earlier BGS $\geq 5$ and $10^{\circ} \mathrm{C}$ was more dominant than the delayed EGS $\geq 5$ and $10^{\circ} \mathrm{C}$, whereas from 2001 to 2010 , for the growing season defined in terms of $T_{\text {mean }} \geq 15^{\circ} \mathrm{C}$, the later EGS $(5.6$ days decade $\left.{ }^{-1}\right)$ was more significant than the earlier BGS (0.1 days decade $\left.{ }^{-1}\right)$. Similar results at the European level were reported by [35], with the delay in EGS by 8.2 days being more significant than the advance in BGS by 3.2 days during 20002008.

3.3. Observed Spatial Variability of Start, End, and Length of Growing Seasons. The GS parameters exhibited clear spatial variability. For clarity of presentation, the locations of specific fields and the Elbe River across the lowlands were added to the maps. Over the past 51 years, the $\mathrm{GS} \geq 5^{\circ} \mathrm{C}$ started between March 11 and 26, and a start before March 11 was calculated for the northeastern Prague plateau (Figure 4). Overall, this is a spatial difference of 15 days. Thus, the BGS $\geq 5^{\circ} \mathrm{C}$ started 4 days later per $100 \mathrm{~m}$ of altitude. The map of $\mathrm{BGS} \geq 5^{\circ} \mathrm{C}$ defines two main areas with a start of the growing season before March 21. These areas can be considered climatically close to the optimum for field vegetable production. However, the occurrence of severe frosts $\left(T_{\min } \leq-2.2^{\circ} \mathrm{C}\right)$ during the planting of field frost-resistant vegetables in the growing area of the Elbe lowland is, on average, 56.9\% [9]. It follows that, despite the considerable resistance of these vegetables to low temperatures, it is necessary to choose planting areas with southern exposures (or cover plants with nonwoven textiles). Utilising resistant varieties and hardening seedlings before planting are advisable. Over the studied region, the $\mathrm{GS} \geq 10^{\circ} \mathrm{C}$ starts nearly 4 weeks after $\mathrm{BGS} \geq 5^{\circ} \mathrm{C}$. Geostatistical analysis indicates that the $\mathrm{BGS} \geq 10^{\circ} \mathrm{C}$ starts roughly 2 days later for every $100 \mathrm{~m}$ of elevation. Consequently, the $\mathrm{BGS} \geq 10^{\circ} \mathrm{C}$ starts between April 15 and 30, and a start before April 15 can be observed in the traditional vegetable-growing regions (up to $300 \mathrm{~m}$ ). In the warmest areas of the middle Elbe lowland, the middle Poohrí, and the northeast of the Prague platform, the mean date of the BGS $\geq 10^{\circ} \mathrm{C}$ occurs between April 16 and 20. Conversely, in the hilly lands of the northern and eastern parts of the Elbe River lowland, the start of BGS $\geq 10^{\circ} \mathrm{C}$ occurs in the end of April. In addition, most vegetables grown in the warmest areas fall within the low-risk category for severe spring frosts. It will therefore be possible to extend the areas suitable for growing cold-resistant vegetables (i.e., mostly Brassicas) towards the northeast of the middle Elbe lowland.
The BGS $\geq 15^{\circ} \mathrm{C}$ starts between May 8 and 18, approximately 1.8 days later per $100 \mathrm{~m}$ of altitude. The latest beginning dates of BGS $\geq 15^{\circ} \mathrm{C}$ after May 15 are related to high altitudes in the region (higher than $300 \mathrm{~m}$ ) and frost hollows, whereas the earliest starts before May 8 are observed in the lower areas (lower than $250 \mathrm{~m}$ ). The risk of frost after May 15 in the traditional vegetable-growing regions (up to $250 \mathrm{~m}$ ) is low. At higher altitudes, areas with zero incidences of negative minimum temperatures were found, which may allow for the possible expansion of the area of thermophilic vegetable cultivation [9].

Over the Elbe River lowland, compared with the start of the growing season, the end of the growing season pattern follows the altitudinal gradient to a lesser degree. There are no large differences in the spatial distribution of the growing season end between $T_{\text {mean }} \geq 5,10$, and $15^{\circ} \mathrm{C}$ (middle panel of Figure 4). The EGS $\geq 5^{\circ} \mathrm{C}$ dates range from 298 days (October 25 ) to 314 days (November 10), and their spatial distributions are inversely related to the climatology of the BGS dates. In $15 \%$ of the study area (hilly lands and frost hollows), the earliest end of the EGS $\geq 5,10$, and $15^{\circ} \mathrm{C}$ occurs before October 31 , October 5, and September 5, respectively. The latest ending of EGS $\geq 5,10$, and $15^{\circ} \mathrm{C}$ (after November 6, October 11, and September 11) occurs in the northeastern Prague plateau and the middle Elbe River valley, which together cover $20 \%$ of the study area. The later end of the growing season in those regions is consistent with an observed earlier start of the growing season in the same region.

The pattern in GSL is consistent with the pattern in the onset of the growing season; GSL pattern also shows some local differences due to the heterogeneous end of the growing season pattern, especially for $T_{\text {mean }} \geq 15^{\circ} \mathrm{C}$ (right panel of Figure 4). A total of $50 \%$ of the area of the Elbe River lowland has a GSL $\geq 5^{\circ} \mathrm{C}$ longer than 225 , which satisfies the requirements of root vegetables (celeriac), which have the longest growing seasons. The GSL $\geq 10^{\circ} \mathrm{C}$ is between 150 and 180 days. $65 \%$ of the area has a growing season shorter than 170 days.

\section{Projected Changes in the Dates of the Start and End and the Length of the Growing Season}

An assessment was made of the potential changes in the dates of the BGS, EGS, and GSL for the three threshold 

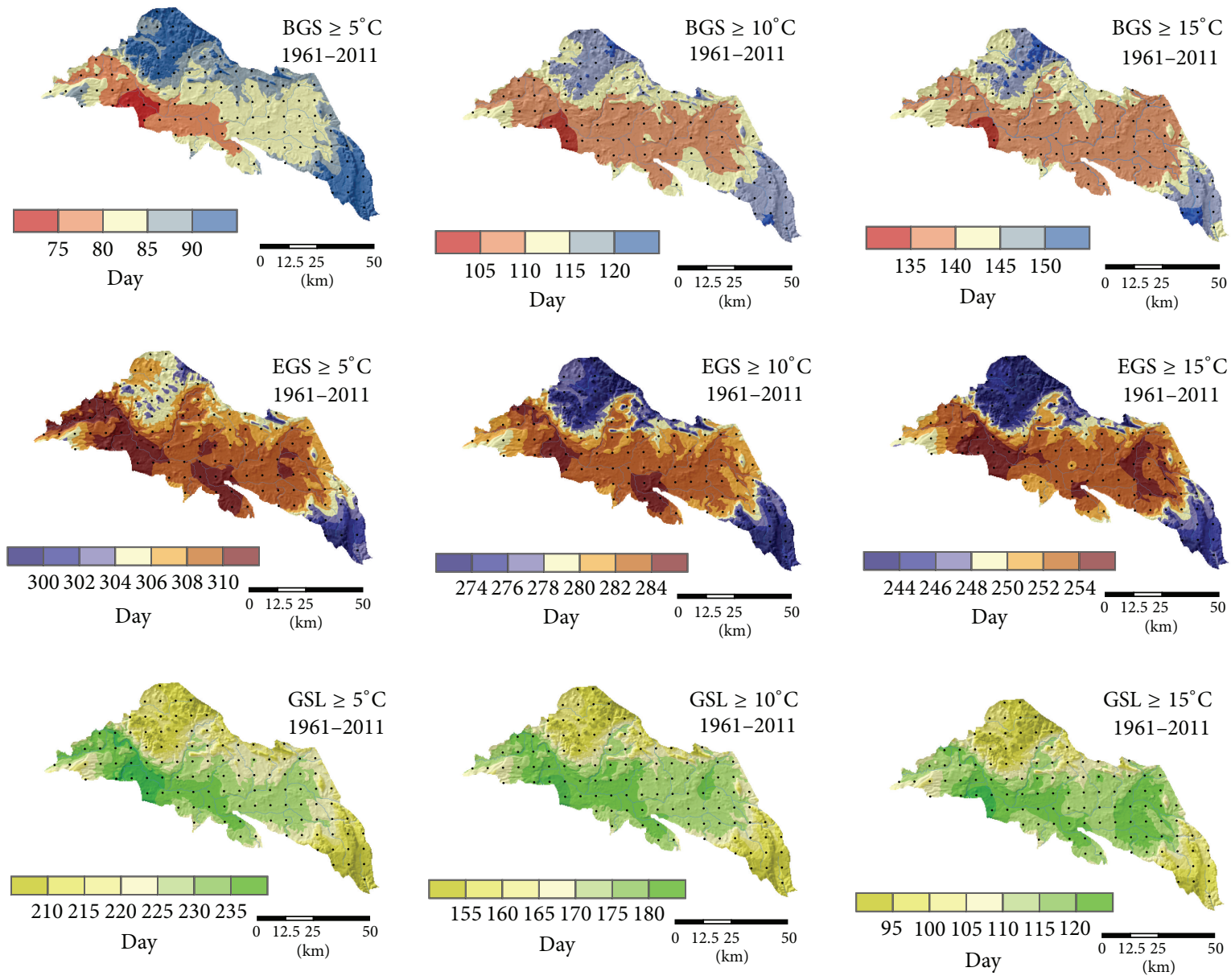

FIGURE 4: Spatial variability of the mean values of BGS, EGS, and GSL for the 5, 10, and $15^{\circ} \mathrm{C}$ temperature thresholds from 1961 to 2011 in the Elbe River lowland.

temperatures over the Elbe River lowland, simulated using the RCMs under the A1B SRES scenario (2021-2050 and 2071-2100). Hovmoller-type diagram displays (Figure 5) the spatiotemporal evolution of large growing season, the main growing season, and the summer growing season projected from 116 grid points over the Elbe River lowland based on ALADIN-Climate/CZ and RegCM simulations data under the A1B SRES scenario runs (2021-2050 and 2071-2100). The use of the RCMs made it possible to estimate potential changes in the GS parameters and identify prospective areas for growing thermophilic vegetables in the Elbe River basin. It is worth noting that, in addition to the types of vegetables traditionally grown in the Elbe River valley, extension of the cultivation of thermophilic varieties, especially Cucumis melo L., has already been observed [9]. This extension is closely linked to warming of the climate system. Consequently, the cultivation of thermophilic vegetables will complement the cultivation of traditional assortment of vegetables. Thus, a detailed evaluation of the past long-term changes in the GS parameters is essential for predicting the effect of future climate variability on the range of vegetables that can be cultivated in this region.
4.1. Temporal Variability of the Projection of BGS, EGS, and GSL. The projected dates of the start, end, and length of the growing season across the Elbe lowland as a whole for the three threshold temperatures and the two future periods considered (2021-2050 and 2071-2100) are presented in Table 4. For both RCMs the dominant dates of $B G S \geq 5,10$ and $15^{\circ} \mathrm{C}$ are projected to advance significantly (i.e., occur earlier) than under the current climate conditions. According to ALADIN-Climate/CZ, in the mid-21st century period, the medians $\mathrm{BGS} \geq 5,10$, and $15^{\circ} \mathrm{C}$ are projected to advance to days 81 (22 Mar), 107 (17 Apr), and 141 (21 May), respectively. At the end of the 21st century, the medians are projected to advance significantly, to days 59 (28 Feb), 81 (22 Mar), and 133 (13 May), respectively. A similar pattern was shown by RegCM (Table 4). These shifts reflect the higher projected temperatures in the $\mathrm{A} 1 \mathrm{~B}$ scenario. The earliest and latest starts of $B G S \geq 5,10$, and $15^{\circ} \mathrm{C}$ for the period 2021-2050 are projected to occur on days 51 (20 Feb.), 80 (21 Mar.), and 120 (30 Apr.), respectively, and on days 107 (17 Apr.), 123 (3 May), and 166 (15 Jun.), respectively. The earliest onset of BGS $\geq 5$ is projected to shift significantly towards the winter season by the end of the 21st century (2071-2100). 


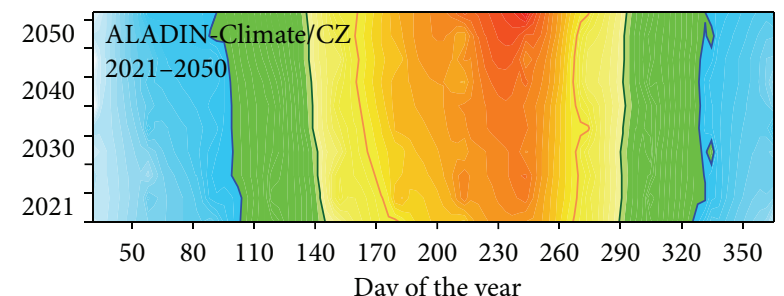

Day of the year
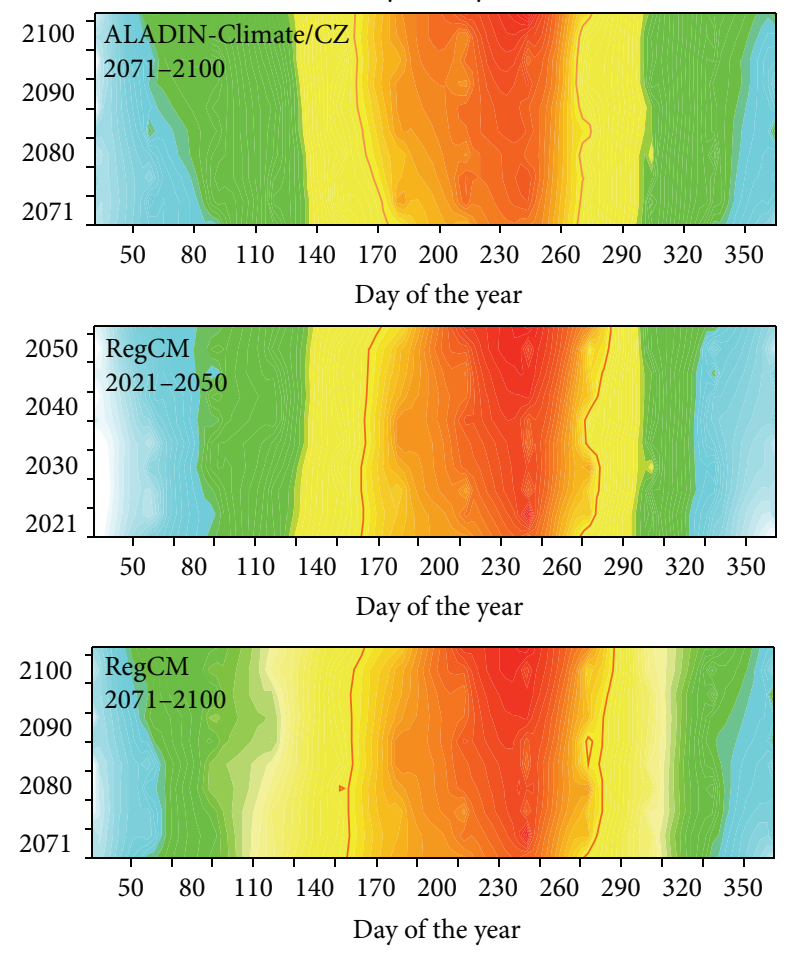

$\begin{array}{ll}\square T_{\text {mean }} \leq 5^{\circ} \mathrm{C} & \square \text { Main GS } \\ \square \text { Long GS } & \square \text { Summer GS }\end{array}$

FIGURE 5: Hovmoller-type diagram of the spatiotemporal evolution of large growing season $\left(T_{\text {mean }} \geq 5^{\circ} \mathrm{C}\right)$, the main growing season $\left(T_{\text {mean }} \geq 10^{\circ} \mathrm{C}\right)$, and the summer growing season $\left(T_{\text {mean }} \geq 15^{\circ} \mathrm{C}\right)$ projected from 116 grid points $\times 30$ years $\times 365$ days over the Elbe River lowland based on ALADIN-Climate/CZ and RegCM simulation data under the A1B SRES scenario runs (2021-2050 and 2071-2100).

In general for both RCMs, the end of the growing season is projected to be significantly delayed (i.e., occur later) under the climate change scenario compared with the current climate. The medians of the EGS $\geq 5,10$, and $15^{\circ} \mathrm{C}$ by ALADIN-Climate/CZ are projected to occur on days 315 (11 Nov.), 284 (11 Oct.), and 255 (12 Sep.), respectively, during 2021-2050. The delay will be greatest during the period 20712100 , when the mean dates of $\mathrm{EGS} \geq 5,10$, and $15^{\circ} \mathrm{C}$ are projected to occur on days 318 (14 Nov.), 293 (20 Oct.), and 267 (24 Sep.), respectively. The latest dates of the end of EGS $\geq 5,10$, and $15^{\circ} \mathrm{C}$ for the period 2021-2050 are projected to occur on days 345 (11 Dec.), 302 (29 Oct.), and 273 (30 Sep.), respectively. The later end of the growing season will extend the vegetation period of field vegetables. The ALADINClimate/CZ and RegCM simulations project an increase in the average growing season length; however, high interannual variability is projected, as in the current climate (Table 4). Under the A1B scenario for the period 2021-2050, the shortest and longest GSL $\geq 5^{\circ} \mathrm{C}\left(\mathrm{GSL} \geq 10\right.$ and $\left.15^{\circ} \mathrm{C}\right)$ vary between 182 (154 and 86 days) and 272 (207 and 140 days) days. Our regional projections for the end of the 21st century indicate that $\mathrm{GSL} \geq 5^{\circ} \mathrm{C}$ (GSL $\geq 10$ and $15^{\circ} \mathrm{C}$ ) could be significantly extended by an average of 267 days (212 and 134 days).

Table 5 displays the predicted changes in the mean start, end, and length of the GS between the reference period (19712000) and the two future climate periods (2021-2050 and 2071-2100) for the Elbe lowland. As expected, the magnitudes of the changes for the two future periods are different. The projections based on two different RCMs by A1B scenario suggest that, during the mid-21st century, the dates of the BGS $\geq 5,10$, and $15^{\circ} \mathrm{C}$ will be earlier (by $\geq 5$ days) and those of the EGS $\geq 5,10$, and $15^{\circ} \mathrm{C}$ will be later (by $\geq 5$ days) across the studied region. Consequently, the GSL $\geq 5^{\circ} \mathrm{C}$ (GSL $\geq$ 10 and $15^{\circ} \mathrm{C}$ ) will be increased under the A1B scenario by $\geq 11$ days ( $\geq 13$ and $\geq 11$ days) compared with the current climate.

The advance of $\mathrm{BGS} \geq 5,10$, and $15^{\circ} \mathrm{C}$ will be greater at the end of the 21st century (by $\geq 15$ days). The ALADINClimate/CZ simulation for the period 2070-2100 projects delays in the EGS $\geq 5,10$, and $15^{\circ} \mathrm{C}$ by 12,13 , and 14 days, respectively, whilst RegCM simulation for the period 20702100 also projects delays in the EGS $\geq 5,10$, and $15^{\circ} \mathrm{C}$ by 12,18 , and 19 days, respectively. The ALADIN-Climate/CZ simulation for the $\mathrm{BGS} \geq 5^{\circ} \mathrm{C}$ start will be advanced by 22 days, and the EGS $\geq 5^{\circ} \mathrm{C}$ end will be delayed by 12 days for the period 2071-2100. Therefore, the A1B scenario results in a projected lengthening of the GSL by 44 days on average compared with the current climate.

\subsection{Spatial Distribution of BGS, EGS, and GSL Projections.}

For the Czech Republic as a whole, the daily mean, maximum, and minimum temperatures simulated by ALADINClimate/CZ and RegCM for the $\mathrm{AlB}$ scenario are projected to increase more in Bohemia than in Moravia and at higher altitudes [27]. These temperature changes affect the growing season parameters, and thus, ALADIN-Climate/CZ and RegCM project greater changes in those parameters for the hilly lands of the Elbe River lowland. According to the ALADINClimate/CZ simulation for the period 2021-2050, at higher elevations in the Elbe lowland the GSL will correspond to that of the warmest areas in the current climate (Figures 6(a) and $6(\mathrm{~b})$ ). The lengthening of the growing season is most apparent for GSL $\geq 5$ and $10^{\circ} \mathrm{C}$. At the end of the 21st century, the GSL in the hottest areas will be significantly lengthened. Additionally, the areas with suitable conditions for growing vegetables (i.e., significant advance and delay of GS) will shift from the lowlands of the Elbe River valley to higher elevations (Figures 6(a) and 6(b)). However, profitable cultivation of vegetables in these areas is complicated by the complex sloping terrain. Therefore, the shift of areas with longer GSL from lowlands to higher elevations could lead to higher potential agroclimatic productivity, which will, however, be difficult to utilise due to the lack of water resources for irrigation and the inaccessibility of these areas to machinery. 

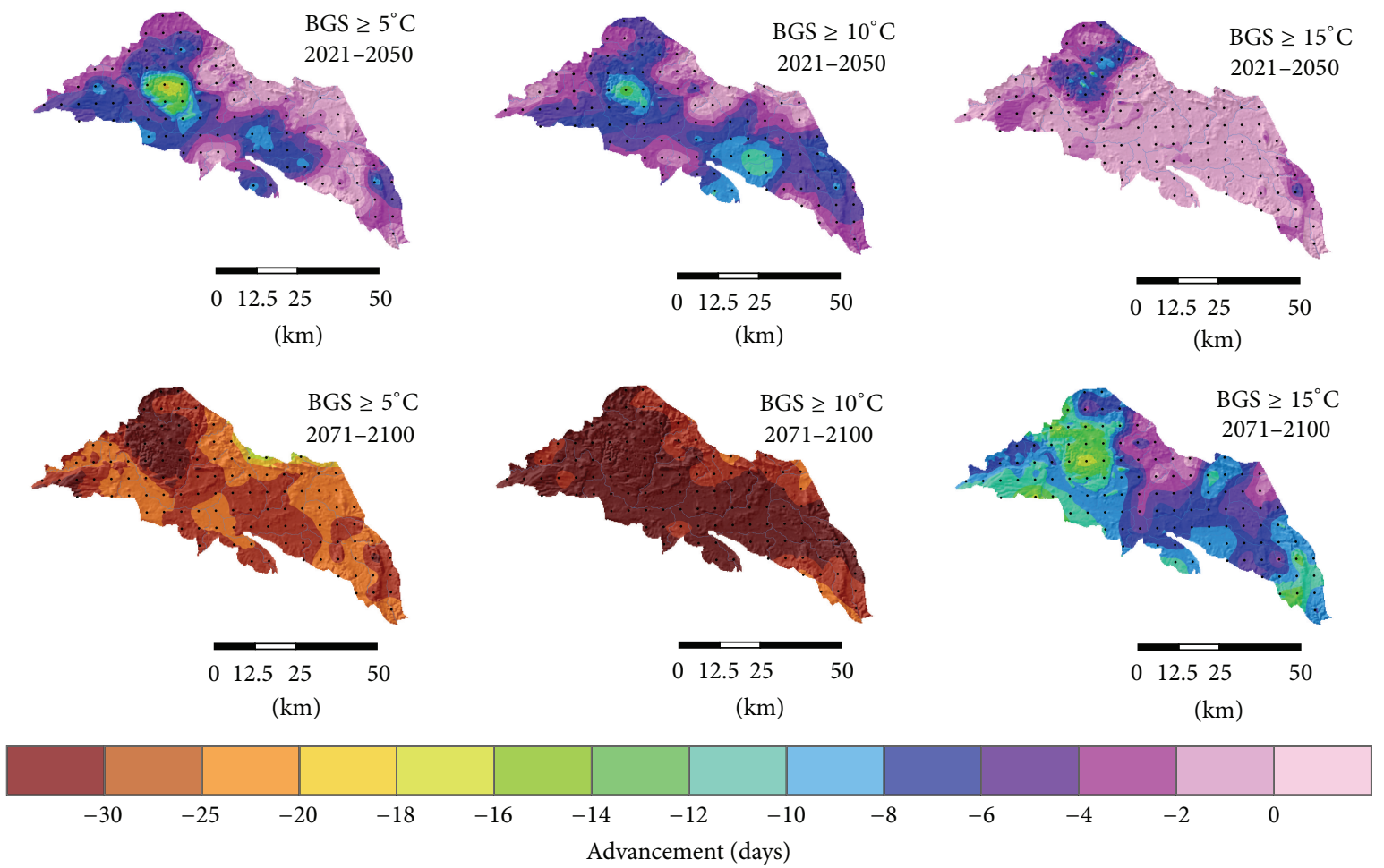

(a)
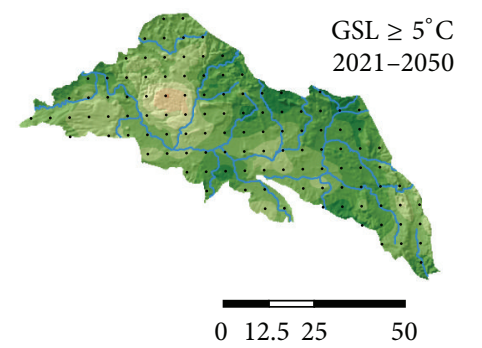

(km)
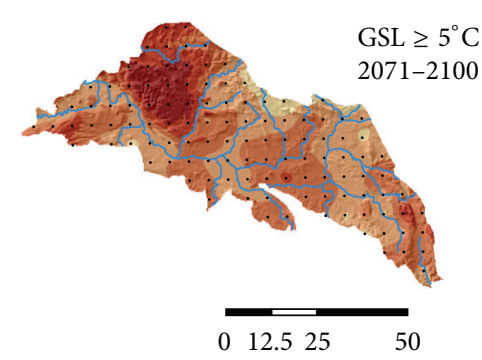

(km)
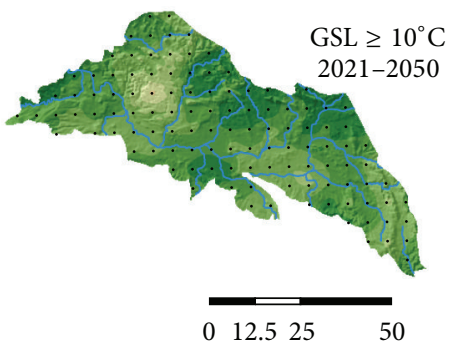

$(\mathrm{km})$
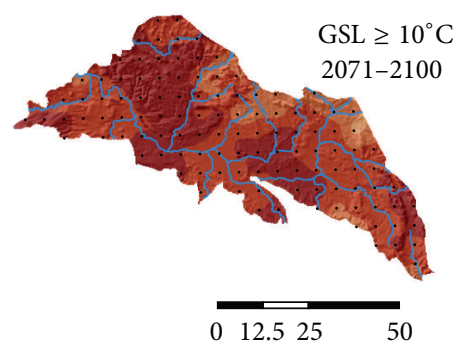

(km)

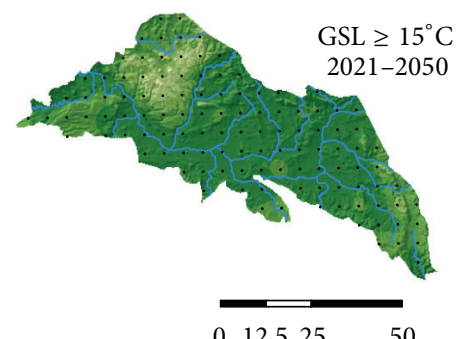

$(\mathrm{km})$
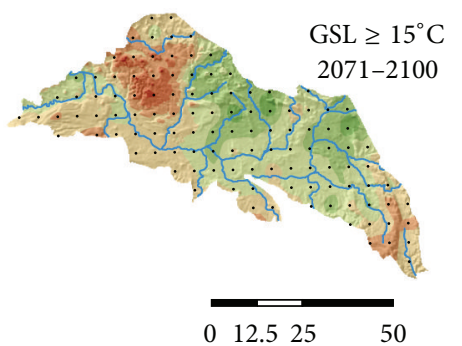

$(\mathrm{km})$

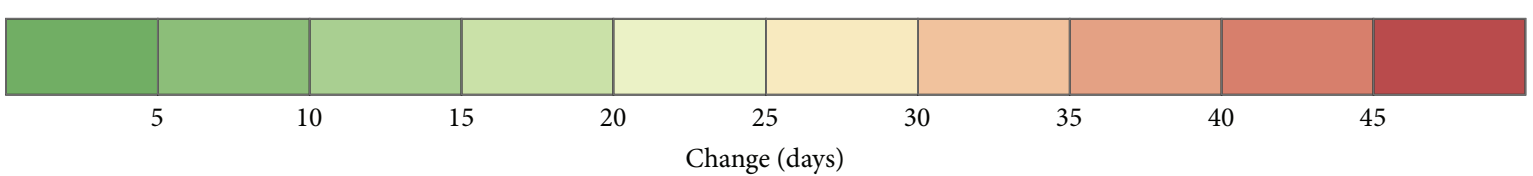

(b)

FIGURE 6: Spatial distribution of projected changes in BGS (a) and GSL (b) for the three threshold temperatures based on ALADINClimate/CZ simulation data under the A1B SRES scenario for two future periods, 2021-2050 and 2071-2100, over the Elbe River lowland. 
TABLE 4: Projected dates of the start, end, and length of the regional growing season for two future periods (2021-2050 and 2071-2100) based on two different RCMs by A1B scenario run over the Elbe River lowland.

\begin{tabular}{|c|c|c|c|c|c|c|c|c|c|}
\hline & \multicolumn{3}{|c|}{$T_{\text {mean }} \geq 5^{\circ} \mathrm{C}$} & \multicolumn{3}{|c|}{$T_{\text {mean }} \geq 10^{\circ} \mathrm{C}$} & \multicolumn{3}{|c|}{$T_{\text {mean }} \geq 15^{\circ} \mathrm{C}$} \\
\hline & Start & End & Length & Start & End & Length & Start & End & Length \\
\hline \multicolumn{10}{|c|}{ 2021-2050 by ALADIN-Climate/CZ (RegCM) } \\
\hline Median & $\begin{array}{c}81 \\
(82)\end{array}$ & $\begin{array}{c}315 \\
(316)\end{array}$ & $\begin{array}{c}234 \\
(234)\end{array}$ & $\begin{array}{c}107 \\
(100)\end{array}$ & $\begin{array}{c}284 \\
(290)\end{array}$ & $\begin{array}{c}178 \\
(190)\end{array}$ & $\begin{array}{c}141 \\
(135)\end{array}$ & $\begin{array}{c}255 \\
(259)\end{array}$ & $\begin{array}{c}114 \\
(124)\end{array}$ \\
\hline Earliest/shortest & $\begin{array}{c}51 \\
(56)\end{array}$ & $\begin{array}{c}289 \\
(289)\end{array}$ & $\begin{array}{c}182 \\
(178)\end{array}$ & $\begin{array}{c}80 \\
(81)\end{array}$ & $\begin{array}{c}268 \\
(263)\end{array}$ & $\begin{array}{c}154 \\
(165)\end{array}$ & $\begin{array}{l}120 \\
(88)\end{array}$ & $\begin{array}{c}242 \\
(233)\end{array}$ & $\begin{array}{c}86 \\
(91)\end{array}$ \\
\hline Latest/longest & $\begin{array}{c}107 \\
(132)\end{array}$ & $\begin{array}{c}345 \\
(348)\end{array}$ & $\begin{array}{c}272 \\
(257)\end{array}$ & $\begin{array}{c}123 \\
(128)\end{array}$ & $\begin{array}{c}302 \\
(323)\end{array}$ & $\begin{array}{c}207 \\
(243)\end{array}$ & $\begin{array}{c}166 \\
(170)\end{array}$ & $\begin{array}{c}273 \\
(290)\end{array}$ & $\begin{array}{c}140 \\
(171)\end{array}$ \\
\hline \multicolumn{10}{|c|}{ 2071-2100 by ALADIN-Climate/CZ (RegCM) } \\
\hline Median & $\begin{array}{c}59 \\
(60)\end{array}$ & $\begin{array}{c}318 \\
(320)\end{array}$ & $\begin{array}{c}267 \\
(260)\end{array}$ & $\begin{array}{c}81 \\
(80)\end{array}$ & $\begin{array}{c}293 \\
(298)\end{array}$ & $\begin{array}{c}212 \\
(212)\end{array}$ & $\begin{array}{c}133 \\
(128)\end{array}$ & $\begin{array}{c}267 \\
(269)\end{array}$ & $\begin{array}{c}134 \\
(141)\end{array}$ \\
\hline Earliest/shortest & $\begin{array}{c}28 \\
(73)\end{array}$ & $\begin{array}{c}301 \\
(297)\end{array}$ & $\begin{array}{c}225 \\
(198)\end{array}$ & $\begin{array}{c}39 \\
(69)\end{array}$ & $\begin{array}{c}281 \\
(262)\end{array}$ & $\begin{array}{c}175 \\
(157)\end{array}$ & $\begin{array}{c}84 \\
(95)\end{array}$ & $\begin{array}{c}247 \\
(242)\end{array}$ & $\begin{array}{c}93 \\
(107)\end{array}$ \\
\hline Latest/longest & $\begin{array}{c}85 \\
(116)\end{array}$ & $\begin{array}{c}344 \\
(350)\end{array}$ & $\begin{array}{c}310 \\
(259)\end{array}$ & $\begin{array}{c}110 \\
(128)\end{array}$ & $\begin{array}{c}310 \\
(322)\end{array}$ & $\begin{array}{c}262 \\
(243)\end{array}$ & $\begin{array}{c}170 \\
(153)\end{array}$ & $\begin{array}{c}285 \\
(311)\end{array}$ & $\begin{array}{c}187 \\
(185)\end{array}$ \\
\hline
\end{tabular}

TABLE 5: Projected changes in the dates of the start, end, and length of the area-averaged growing season for two future periods (2021-2050 and 2071-2100) over the Elbe River lowland.

\begin{tabular}{|c|c|c|c|c|c|c|c|c|c|}
\hline & \multicolumn{3}{|c|}{$T_{\text {mean }} \geq 5^{\circ} \mathrm{C}$} & \multicolumn{3}{|c|}{$T_{\text {mean }} \geq 10^{\circ} \mathrm{C}$} & \multicolumn{3}{|c|}{$T_{\text {mean }} \geq 15^{\circ} \mathrm{C}$} \\
\hline & Start & End & Length & Start & End & Length & Start & End & Length \\
\hline \multicolumn{10}{|c|}{ ALADIN-Climate/CZ by A1B scenario run } \\
\hline 2021-2050 & $\begin{array}{c}\text { Advance } \\
10\end{array}$ & $\begin{array}{c}\text { Delay } \\
6\end{array}$ & $\begin{array}{c}\text { Increase } \\
16\end{array}$ & $\begin{array}{c}\text { Advance } \\
7\end{array}$ & $\begin{array}{c}\text { Delay } \\
6\end{array}$ & $\begin{array}{c}\text { Increase } \\
13\end{array}$ & $\begin{array}{c}\text { Advance } \\
6\end{array}$ & $\begin{array}{c}\text { Delay } \\
5\end{array}$ & $\begin{array}{c}\text { Increase } \\
11\end{array}$ \\
\hline $2071-2100$ & $\begin{array}{c}\text { Advance } \\
22\end{array}$ & $\begin{array}{c}\text { Delay } \\
12 \\
\end{array}$ & $\begin{array}{c}\text { Increase } \\
44\end{array}$ & $\begin{array}{c}\text { Advance } \\
32\end{array}$ & $\begin{array}{c}\text { Delay } \\
13 \\
\end{array}$ & $\begin{array}{c}\text { Increase } \\
45\end{array}$ & $\begin{array}{c}\text { Advance } \\
15\end{array}$ & $\begin{array}{c}\text { Delay } \\
14\end{array}$ & $\begin{array}{c}\text { Increase } \\
29\end{array}$ \\
\hline \multicolumn{10}{|c|}{ RegCM by A1B scenario run } \\
\hline 2021-2050 & $\begin{array}{c}\text { Advance } \\
5\end{array}$ & $\begin{array}{c}\text { Delay } \\
7\end{array}$ & $\begin{array}{c}\text { Increase } \\
11\end{array}$ & $\begin{array}{c}\text { Advance } \\
11\end{array}$ & $\begin{array}{c}\text { Delay } \\
10\end{array}$ & $\begin{array}{c}\text { Increase } \\
21\end{array}$ & $\begin{array}{c}\text { Advance } \\
6\end{array}$ & $\begin{array}{c}\text { Delay } \\
9\end{array}$ & $\begin{array}{c}\text { Increase } \\
15\end{array}$ \\
\hline $2071-2100$ & $\begin{array}{c}\text { Advance } \\
27\end{array}$ & $\begin{array}{c}\text { Delay } \\
12\end{array}$ & $\begin{array}{c}\text { Increase } \\
37\end{array}$ & $\begin{array}{c}\text { Advance } \\
31\end{array}$ & $\begin{array}{c}\text { Delay } \\
18\end{array}$ & $\begin{array}{c}\text { Increase } \\
49\end{array}$ & $\begin{array}{c}\text { Advance } \\
13\end{array}$ & $\begin{array}{c}\text { Delay } \\
19\end{array}$ & $\begin{array}{c}\text { Increase } \\
32\end{array}$ \\
\hline
\end{tabular}

Significant changes in the BGS can be expected mostly in hilly areas (Figures 6(a) and 6(b)). At the end of the 21st century, two main areas with different early growing season onsets will stand out: the area with the earliest onset of BGS, which will be located in the northwestern Elbe River lowland (i.e., in areas of frost hollows and hills), and a newly created region, which corresponds to currently peripheral areas of vegetable farmland (eastern part of Elbe River valley). The ALADINClimate/CZ and RegCM simulations reveal that, by the end of this century, Czech farmers could be growing their crops for up to two months longer. The Elbe River lowland can become a major producer of vegetables in the Czech Republic and significantly increase its competitiveness in the production of market vegetables.

Our results show that, under the $\mathrm{AlB}$ scenario for the two future climate periods considered (2021-2050 and 2071$2100)$, the projected increases in the growing season are due to significant projected advances of the starts of BGS $\geq 5,10$, and $15^{\circ} \mathrm{C}$. The BGS simulation data also show clear tendencies towards an earlier start, especially for GSL $\geq 5$ and $10^{\circ} \mathrm{C}$. The end of the growing season is projected to occur later on average, but these projected shifts are smaller than those for the beginning of the growing season. Based on these results, it is evident that regional climate changespecifically, increases in temperatures during the growing season-will affect Czech vegetable crops. The changes in the Elbe lowland climate are expected to significantly advance the sowing/planting dates of vegetables under current and future climate conditions. Similar findings have been reported for agricultural areas worldwide $[4,6,11,12,30,33,35,36,38]$.

\section{Summary and Concluding Remarks}

In this study, a comprehensive analysis of the current climatic conditions (1961-2011) and possible changes in the climate in the near future (2021-2050) and at the end of the century (2071-2100) was undertaken using both observed gridded data and two RCMs driven by two different GCMs of the 
changes in the timing of GS parameters for the Elbe River lowland for the first time. The ALADIN-Climate/CZ and RegCM models, with a high horizontal resolution of $10 \mathrm{~km}$, provided the daily step temperature series to project changes in the GS parameters. The date of sowing/planting and the harvest period depend on the vegetable variety, agroclimatic conditions, commercial targets, market constraints, and horticultural practices. This is the probable reason for the absence of data on the sowing/planting and harvest dates of vegetables in the Czech Republic and in other countries. Systematically recorded information on phenology is utterly lacking for most types of vegetables at both the local and the global scales [16].

This research aimed to identify an approach to select suitable sites for extension of new thermophilic assortment of vegetables in Elbe lowland, taking into account regional specificity of climate change, and also to determine prospective areas for growing thermophilic vegetables in the study region using regional climate models. Proposed study can be crucial in development of strategies on climate change adaptation for different varieties of thermophile crops for future climate change in different regions in order to increase productivity while reducing both the cost of farmers and the water footprint of agriculture per unit product. Moreover, our study is in line with the two aims defined in the EU strategy for adaptation of agricultural production system through scientific research and other actions to advance sustainable agriculture development that benefits local, regional, and European farmers and to develop climate-informed crop. The results can be also relevant to the European policy, especially to the Common Agricultural Policy by contributing to good agricultural practices and sustaining the rural communities. The high degree of uncertainty in expected temperature and precipitation changes implies investment risks for deciding on long-term changes in farming technology such as adopting irrigation or switching to new crops, requiring new machinery, infrastructure, and agronomic and market knowledge [39]. The salient results are summarised below.

(i) The temporal evolution of anomalies in the GS onset, end, and length displays two distinct periods: a delay in the onset in spring and a shortening of the GSL in the 1960s and an intensified lengthening of the GSL since the 1990s. The majority of years with strong delays in the onset and/or decrease in the length of the growing season occurred in the decade of 1971-1980, which was cooler and wetter than the other decades of the reference period analysed. In the last two decades of the period (1991-2011), BGS and EGS exhibited significant shifts to earlier and later dates, respectively. Consequently, the end of the 20th century and the beginning of the 21st century will be a suitable period for the extension of the cultivation of varieties of vegetables with longer growing seasons and higher temperature requirements.

(ii) From 1961 to 2011, the Elbe River lowland experienced increasingly negative BGS and positive EGS trends that led to an increasing GSL trend. However, the roles of the changes in BGS and EGS differed depending on the time period and on the chosen temperature thresholds. The regional $\mathrm{GS} \geq 5^{\circ} \mathrm{C}\left(\geq 10\right.$ and $\left.15^{\circ} \mathrm{C}\right)$ started 10.7 days (7.6 d and $3.1 \mathrm{~d}$ ) earlier and ended 4.6 days ( $3.6 \mathrm{~d}$ and $4.1 \mathrm{~d}$ ) later, yielding an increase in GSL of 15.3 days (11.2 d and 7.2 d) from 1961 to 2011. The delay in EGS was found to be a more important factor than the advance in BGS in regulating the GSL changes during the 1990s and 2000s at the threshold of $T_{\text {mean }} \geq 15^{\circ} \mathrm{C}$.

(iii) Under projected future climate conditions and temperature thresholds, the dominant dates of BGS and EGS for the entire study region are projected to be significantly advanced and delayed, respectively, compared with the current climate. A climate warming scenario suggests lengthening of the GSL in the coldest areas of the study region to the level of the warmest areas in the current climate. According to the RCMs simulation, the most significant shifts in the dates of the beginning and end of the GS are projected to occur in hilly areas; in lowland areas, these changes are not projected to be as pronounced. The lengthening of the GSL and the flat topography plateaus will create favourable conditions for the expansion of vegetables areas, mainly towards the eastern part of the Elbe River basin. The results also suggest potential for a northerly expansion of vegetables cultivation, although most of the lands to the north of the current frontier will remain only marginally suitable for growing field vegetables due to their complex terrain.

This study can be considered an initial step towards assessing the potential impacts of climate change on the types of vegetable crops grown in the Elbe River lowland. In our future work, we plan to use mechanistic crop simulation models (e.g., CROPGRO-Tomato model) and multimodel multiscenario ensemble (for the new emission scenarios RCP4.5 and RCP8.5) to project potential consequences of climate change on fresh-market tomato (Solanum lycopersicum L.) grown under open field conditions at farm scale in the Elbe lowland.

\section{Conflict of Interests}

The authors declare that there is no conflict of interests regarding the publication of this paper.

\section{Acknowledgments}

This research was supported by Institutional Support Program for Long Term Conceptual Development of Research Institution provided by Ministry of Education, Youth and Sports of the Czech Republic and InterDrought CZ.1.07/ 2.3.00/20.0248. This study was also funded by the project Global and Regional Climate Model Simulations in Central Europe in the 18th-20th Centuries in Comparison with Observed and Reconstructed Climate, no. GAP209/11/0956. The authors are grateful to the associate editor (Macros Heil Costa) and two anonymous reviewers for their constructive comments and suggestions. 


\section{References}

[1] IPCC, Working Group I Contribution to the IPCC Fifth Assessment Report Climate Change 2013: The Physical Science Basis, 2013.

[2] J. Alcamo, J. M. Moreno, B. Nováky et al., in Climate Change 2007: Impacts, Adaptation and Vulnerability, M. L. Parry, O. F. Canziani, J. P. Palutikof, P. J. van der Linden, and C. E. Hanson, Eds., Contribution of Working Group II to the Fourth Assessment Report of the Intergovernmental Panel on Climate Change, pp. 541-580, Cambridge University Press, Cambridge, UK, 2007.

[3] C. Rosenzweig, G. Casassa, D. J. Karoly et al., "Assessment of observed changes and responses in natural and managed systems," in Climate Change 2007: Impacts, Adaptation and Vulnerability. Contribution of Working Group II to the Fourth Assessment Report of the Intergovernmental Panel on Climate Change, M. L. Parry, O. F. Canziani, J. P. Palutikof, P. J. van der Linden, and C. E. Hanson, Eds., pp. 79-131, Cambridge University Press, Cambridge, UK, 2007.

[4] M. Bindi and J. E. Olesen, "The responses of agriculture in Europe to climate change," Regional Environmental Change, vol. 11, no. 1, pp. 151-158, 2011.

[5] A. Menzel, J. von Vopelius, N. Estrella, C. Schleip, and V. Dose, "Farmers' annual activities are not tracking speed of climate change," Climate Research, vol. 32, no. 3, pp. 201-207, 2006.

[6] F. N. Tubiello, M. Donatelli, C. Rosenzweig, and C. O. Stockle, "Effects of climate change and elevated $\mathrm{CO}_{2}$ on cropping systems: model predictions at two Italian locations," European Journal of Agronomy, vol. 13, no. 2-3, pp. 179-189, 2000.

[7] F.-M. Chmielewski and T. Rötzer, "Annual and spatial variability of the beginning of growing season in Europe in relation to air temperature changes," Climate Research, vol. 19, no. 3, pp. 257264, 2002.

[8] H. Scheifinger, A. Menzel, E. Koch, and C. Peter, "Trends of spring time frost events and phenological dates in Central Europe," Theoretical and Applied Climatology, vol. 74, no. 1-2, pp. 41-51, 2003.

[9] V. Potop, P. Zahraniček, L. Türkott, P. Štěpánek, and J. Soukup, "Risk occurrences of damaging frosts during the growing season of vegetables in the Elbe River lowland, the Czech Republic," Natural Hazards, vol. 71, no. 1, pp. 1-19, 2014.

[10] F.-M. Chmielewski, A. Müller, and E. Bruns, "Climate changes and trends in phenology of fruit trees and field crops in Germany, 1961-2000," Agricultural and Forest Meteorology, vol. 121, no. 1-2, pp. 69-78, 2004.

[11] D. Tomasi, G. V. Jones, M. Giust, L. Lovat, and F. Gaiotti, "Grapevine phenology and climate change: relationships and trends in the Veneto Region of Italy for 1964-2009," American Journal of Enology and Viticulture, vol. 62, no. 3, pp. 329-339, 2011.

[12] G. Koufos, T. Mavromatis, S. Koundouras, N. M. Fyllas, and G. V. Jones, "Viticulture-climate relationships in Greece: the impacts of recent climate trends on harvest date variation," International Journal of Climatology, vol. 34, no. 5, pp. 14451459, 2014.

[13] M. Trnka, J. Eitzinger, P. Hlavinka et al., "Climate-driven changes of production regions in Central Europe," Plant, Soil and Environment, vol. 55, no. 6, pp. 257-266, 2009.

[14] V. Potopová, P. Štěpánek, M. Možný, L. Türkott, and J. Soukup, "Performance of the standardised precipitation evapotranspiration index at various lags for agricultural drought risk assessment in the Czech Republic," Agricultural and Forest Meteorology, vol. 202, pp. 26-38, 2015.

[15] P. Štěpánek, P. Zahradníček, R. Brázdil, and R. Tolasz, Methodology of Data Quality Control and Homogenization of Time Series in Climatology, Ceský Hydrometeorologický Ústav, Prague, Czech, 2011.

[16] WMO, "Definition of agrometeorological information required for vegetable crops," Tech. Rep. WMO-No. 866, World Meteorological Organization, Geneva, Switzerland, 1997.

[17] E. Pekárková, Cultivate Tomatoes, Peppers and Other Fruit Vegetables, Grada Publishing, 2001, (Czech).

[18] K. Petř́ková and I. Malý, Fundamentals of Growing Fruit Vegetables, Institute of Agricultural and Food Information, Prague, Czech Republic, 2003, (Czech).

[19] IPCC, Climate Change 2007: The Physical Science Basis. Contribution of Working Group I to the IPCC Fourth Assessment Report, Cambridge University Press, Cambridge, UK, 2007.

[20] M. Déqué, C. Dreveton, A. Braun, and D. Cariolle, "The ARPEGE/IFS atmosphere model: a contribution to the French community climate modelling," Climate Dynamics, vol. 10, no. 4-5, pp. 249-266, 1994.

[21] E. Roeckner, G. Bäuml, L. Bonaventura et al., "The Atmospheric General Circulation Model ECHAM 5. part I: model description," MPI Report 349, Max Planck Institute for Meteorology, Hamburg, Germany, 2003.

[22] F. Giorgi, M. R. Marinucci, and G. T. Bates, "Development of a second-generation regional climate model (RegCM2). Part I. Boundary-layer and radiative transfer processes," Monthly Weather Review, vol. 121, no. 10, pp. 2794-2813, 1993.

[23] F. Giorgi, X. Bi, and J. S. Pal, "Means, trends and interannual variability in a regional climate change experiment over Europe. Part I: present day climate (1961-1990)," Climate Dynamics, vol. 22, no. 6-7, pp. 733-756, 2004.

[24] J. S. Pal, F. Giorgi, and X. Bi, "Consistency of recent European summer precipitation trends and extremes with future regional climate projections," Geophysical Research Letters, vol. 31, no. 13, Article ID L13202, 2004.

[25] T. Halenka, J. Kalvová, Z. Chládová, A. Demeterová, K. Zemánková, and M. Belda, "On the capability of RegCM to capture extremes in long term regional climate simulationcomparison with the observations for Czech Republic," Theoretical and Applied Climatology, vol. 86, no. 1-4, pp. 125-145, 2006.

[26] R. Huth, J. Kyselý, L. Pokorná et al., "One month-long integrations of the Aladin model in the climate mode: effect of selected parameters," Meteorological Bulletin, vol. 57, pp. 41-46, 2004 (Czech).

[27] E. Holtanová, J. Mikšovský, J. Kalvová, P. Pišoft, and M. Motl, "Performance of ENSEMBLES regional climate models over Central Europe using various metrics," Theoretical and Applied Climatology, vol. 108, no. 3-4, pp. 463-470, 2012.

[28] M. Déqué, "Frequency of precipitation and temperature extremes over France in an anthropogenic scenario: model results and statistical correction according to observed values," Global and Planetary Change, vol. 57, no. 1-2, pp. 16-26, 2007.

[29] A. Menzel, G. Jakobi, R. Ahas, H. Scheifinger, and N. Estrella, "Variations of the climatological growing season (1951-2000) in Germany compared with other countries," International Journal of Climatology, vol. 23, no. 7, pp. 793-812, 2003.

[30] M. A. White, P. E. Thornton, and S. W. Running, "A continental phenology model for monitoring vegetation responses to interannual climatic variability," Global Biogeochemical Cycles, vol. 11, no. 2, pp. 217-234, 1997. 
[31] T. R. Carter, "Changes in the thermal growing season in Nordic countries during the past century and prospects for the future," Agricultural and Food Science in Finland, vol. 7, no. 2, pp. 161179, 1998.

[32] P. L. Frich, L. V. Alexander, P. Della-Marta et al., "Observed coherent changes in climatic extremes during the second half of the twentieth century," Climate Research, vol. 19, no. 3, pp. 193-212, 2002.

[33] S. Feng and Q. Hu, "Changes in agro-meteorological indicators in the contiguous United States: 1951-2000," Theoretical and Applied Climatology, vol. 78, no. 4, pp. 247-264, 2004.

[34] H. W. Linderholm, A. Walther, and D. Chen, "Twentiethcentury trends in the thermal growing season in the Greater Baltic Area," Climatic Change, vol. 87, no. 3-4, pp. 405-419, 2008.

[35] S. J. Jeong, C. H. Ho, H. J. Gim, and M. E. Brown, "Phenology shifts at start vs. end of growing season in temperate vegetation over the Northern Hemisphere for the period 1982-2008," Global Change Biology, vol. 17, no. 7, pp. 2385-2399, 2011.

[36] X. Yang, Z. Tian, and B. Chen, "Thermal growing season trends in east China, with emphasis on urbanization effects," International Journal of Climatology, vol. 33, no. 10, pp. 2402-2412, 2013.

[37] R. Tolasz, Climate Atlas of Czechia, ČHMÚ, Univerzita Palackého v Olomouci, Praha-Olomouc, 2007.

[38] S. S. P. Shen, H. Yin, K. Cannon, A. Howard, S. Chetner, and T. R. Karl, "Temporal and spatial changes of the agroclimate in Alberta, Canada, from 1901 to 2002," Journal of Applied Meteorology, vol. 44, no. 7, pp. 1090-1105, 2005.

[39] H. S. Lehtonen, R. P. Rotter, T. I. Palosuo et al., "A modelling framework for assessing adaptive management options of Finnish agrifood systems to climate change," Journal of Agricultural Science, vol. 2, no. 2, pp. 3-16, 2010. 

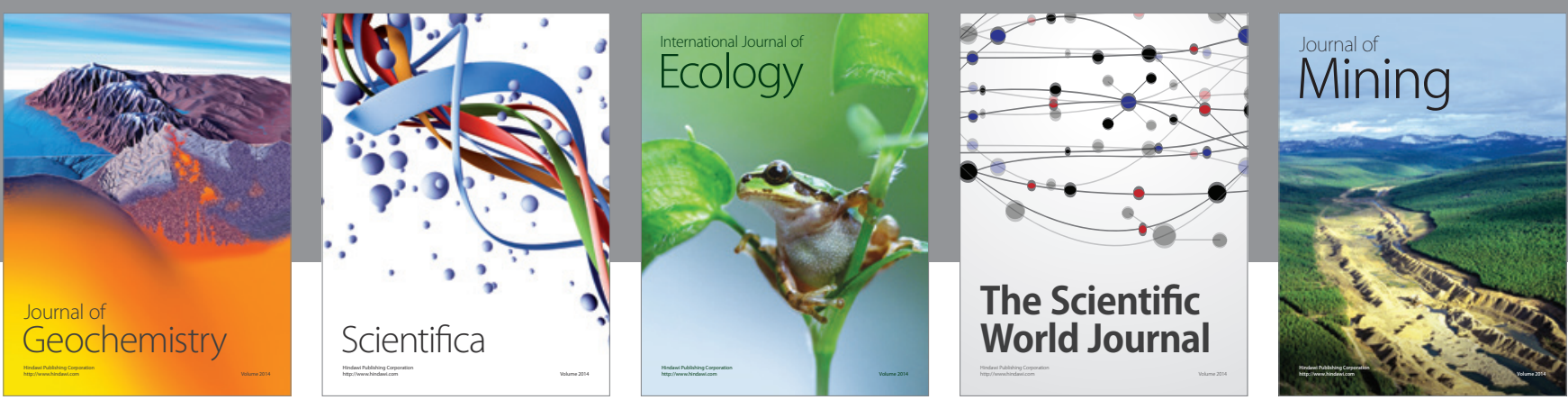

The Scientific World Journal
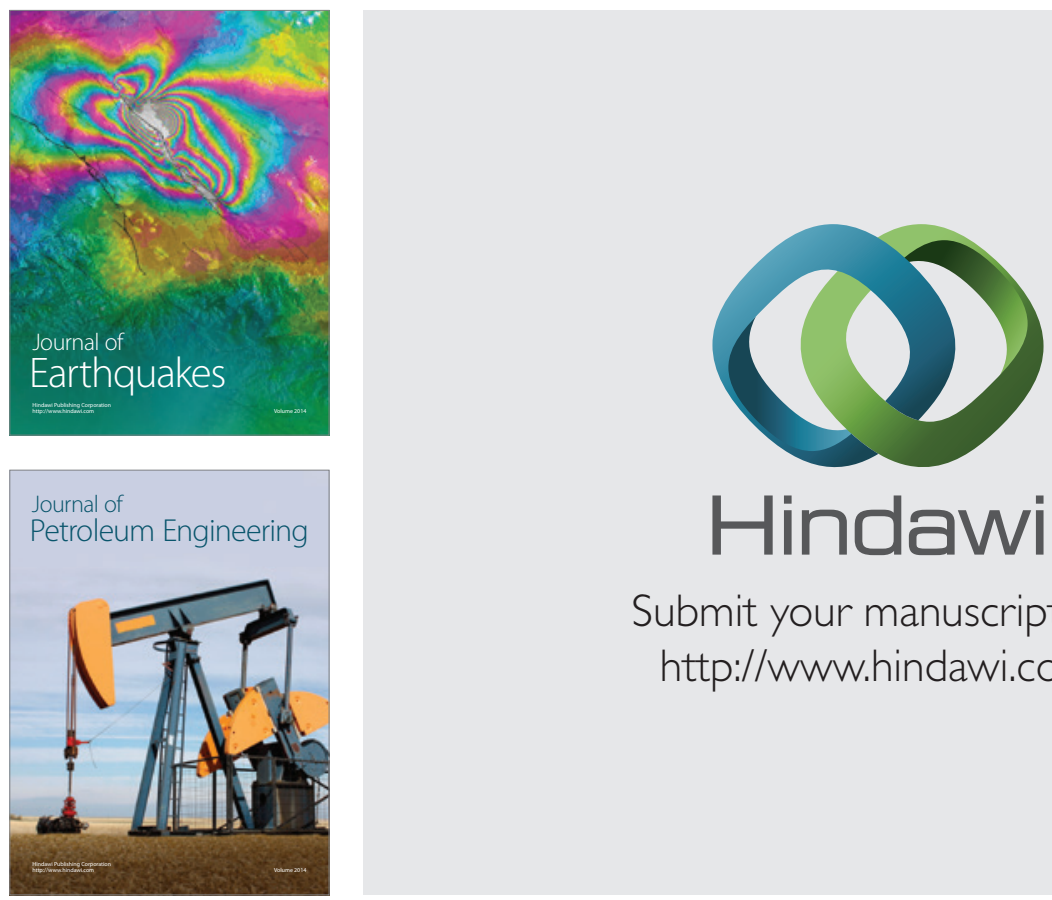

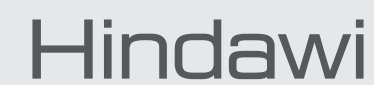

Submit your manuscripts at

http://www.hindawi.com
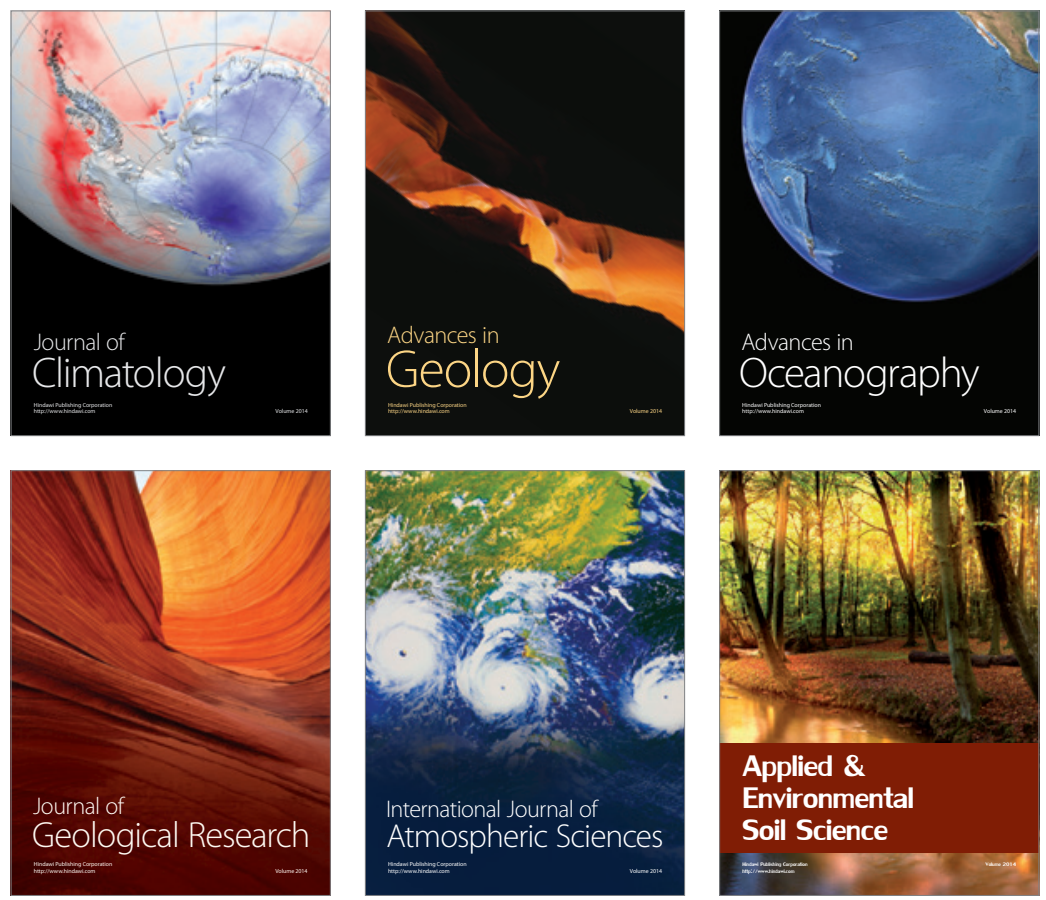
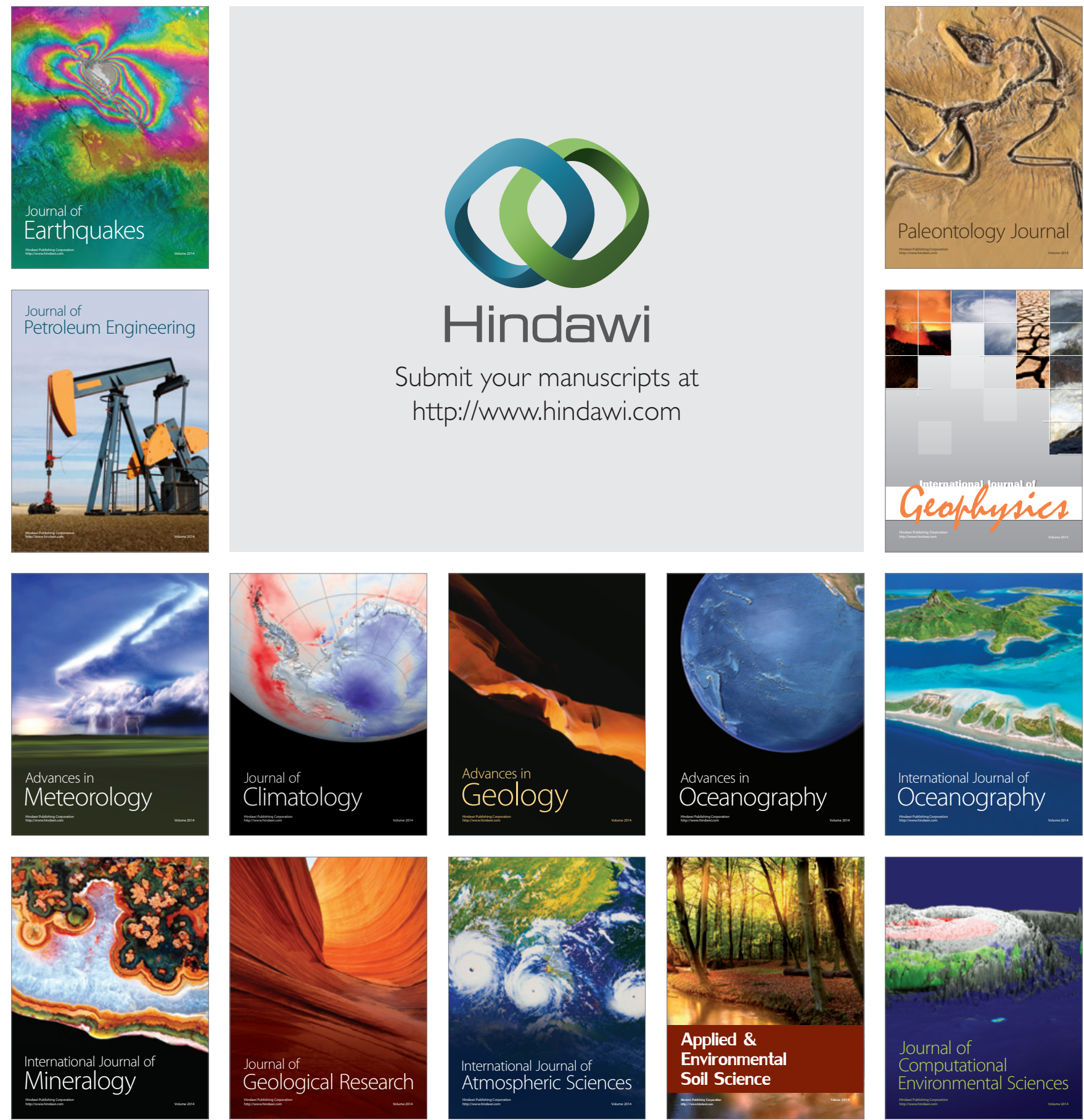